\title{
Elevated Temperature Compressive Properties of Zr-Modified NiAl
}

\section{J. DANIEL WHITTENBERGER and R.D. NOEBE}

Small $\mathrm{Zr}$ additions are known to substantially affect the deformation behavior and strength of polycrystalline $\mathrm{NiAl}$, yet little information is currently available regarding the high-temperature properties of such alloys. Utilizing prealloyed powder technology, a series of four NiAl alloys have been produced containing from 0.05 to 0.7 at. pct $\mathrm{Zr}$. The creep behavior of these alloys was characterized in compression between 1000 and $1400 \mathrm{~K}$ at strain rates ranging from $\sim 0.1$ to $10^{-9} \mathrm{~s}^{-1}$. All the $\mathrm{Zr}$ modified alloys were significantly stronger than binary $\mathrm{NiAl}$ under lower temperature and faster strain-rate conditions; however, the single-phase materials ( $\mathrm{Zr} \leq 0.1$ at. pct) and binary $\mathrm{NiAl}$ had similar strengths at high temperatures and slow strain rates. The two-phase $\mathrm{NiAl}-\mathrm{Ni}_{2} \mathrm{AlZr}$ alloys containing 0.3 and 0.7 at. pet $\mathrm{Zr}$ had nearly identical strengths. While the two-phase alloys were stronger than the single-phase materials at all test conditions, the degree of microstructural damage in the two-phase alloys due to internal oxidation during testing appeared to increase with $\mathrm{Zr}$ level. Balancing the poor oxidation behavior with the consistent strength advantage of the two-phase alloys, it is concluded that optimum elevated-temperature properties could be obtained in Heusler-strengthened NiAl containing between 0.1 and 0.3 at. pct $\mathrm{Zr}$.

\section{INTRODUCTION}

ALTHOUGH the $\mathrm{B} 2$-ordered intermetallic $\mathrm{NiAl}$ has a number of promising properties that make it an attractive replacement material for superalloys (i.e., high melting point, good thermal conductivity, moderate density, and excellent oxidation resistance), it has poor elevated-temperature strength and is seriously lacking in low-temperature tensile ductility and toughness. ${ }^{[1-5]}$ Simple third-element additions have been and are currently being investigated as a means to improve both of these deficiencies. For example, small $(<0.3$ at. pct) amounts of $\mathrm{Fe}, \mathrm{Ga}$, or Mo may improve the low-temperature tensile ductility of $\mathrm{NiAl}$ single crystals, ${ }^{[1]}$ while 0.3 to 1 at. pct Hf or Ta containing NiAl single crystals have high-temperature creep properties approaching those of first-generation single-crystal Ni-based superalloys. ${ }^{[1.5-7]}$

Unfortunately, while polycrystalline, nominally equiatomic $\mathrm{NiAl}$ routinely can be deformed from 0.5 to 3 pct in tension at room temperature, ${ }^{[8]}$ third-element additions have not produced any significant improvement in ductility. In fact, most alloying additions to polycrystalline $\mathrm{NiAl}$ (with the possible exceptions of $\mathrm{W}^{[9]} \mathrm{Be}{ }^{[10]}$ and $\left.\mathrm{N}^{(11)]}\right)$ tend to decrease the room-temperature ductility and increase the brittle-to-ductile transition temperature (BDTT) ${ }^{[4.8]}$ Elevated-temperature strength of polycrystalline $\mathrm{NiAl}$, on the other hand, can be significantly affected by third-element additions. Polvani et al..$^{[12]}$ demonstrated in 1976 that replacement of about 10 at. pct $\mathrm{Al}$ with $\mathrm{Ti}$ will yield polycrystalline $\mathrm{NiAl}-\mathrm{Ni}_{2} \mathrm{AlTi}$ alloys with creep properties approaching those of Ni-based superalloys. Much smaller alloying additions, a few percent or less, of $\mathrm{Re},{ }^{\left[{ }^{[9]}\right.}$ or $\mathrm{Hf}$, $\mathrm{Nb}$, and $\mathrm{Ta}^{[13]}$ also have been reported to significantly increase the elevated-temperature strength of polycrystalline NiAl under fast strain-rate conditions. However, under

J. DANIEL WHITTENBERGER and R.D. NOEBE, Materials Research Engineers, are with NASA Lewis Research Center, Cleveland, OH 44135. Manuscript submitted June 30, 1995. high-temperature and slow strain-rate conditions, the effectiveness of third-element additions, at least for $\mathrm{Hf}^{\left[{ }^{14]}\right.}$ and $\mathrm{Nb},{ }^{[15]}$ is dramatically decreased.

In other work by Raj and co-workers, ${ }^{[16.17]}$ even smallcr additions of $\mathrm{Zr}$, on the order of 0.05 at. pct, were also shown to be extremely effective in strengthening NiAl, at least at strain rates of $10^{-4} \mathrm{~s}^{-1}$. Coupled with the extremely potent strengthening effect of $\mathrm{Zr}^{[16.17]}$ is the substantial influence of this element on the overall mechanical behavior of NiAl. For example, 0.05 at. pct $\mathrm{Zr}$ increases the brittleto-ductile transition temperature of $\mathrm{NiAl}$ from 550 to nearly $850 \mathrm{~K},{ }^{[16.17]}$ while an alloying addition of 0.1 at. pct $\mathrm{Zr}$ raises the BDTT to $1050 \mathrm{~K} \cdot{ }^{[18]}$ The increase in brittle-toductile transition temperature has been attributed to the segregation of $\mathrm{Zr}$ to the grain boundaries in $\mathrm{NiA}{ }^{[19]}$ and the subsequent inhibition of grain boundary deformation mech. anisms. ${ }^{[17.20]}$ Small (0.1 at. pct) additions of $\mathrm{Zr}$ also dra. matically alter the low cycle-fatigue behavior of $\mathrm{NiAl}$ at $1000 \mathrm{~K}^{[21]}$ By reducing creep damage, low levels of $\mathrm{Zr}$ significantly increase the response stresses and fatigue life of $\mathrm{NiAl}$ at low strain ranges. However, fatigue life at highe: strain ranges is reduced compared to binary $\mathrm{NiAl}$ due to the lack of tensile ductility in NiAl-0.1Zr. Finally, smali amounts of $\mathrm{Zr}$ vastly improve the cyclic oxidation behavior of $\mathrm{NiA}^{[22]}$ to the point where all oxidation-resistant nickel aluminide coatings or alloys contain $\mathrm{Zr}$ or some other reactive alloying addition.

In spite of all the research on NiAl alloyed with small amounts of $\mathrm{Zr}$, no further efforts to exploit its strengthening effects have been undertaken. Regardless of the BDTT liability produced by $\mathrm{Zr}$, it still is important to define the limits of this element in its ability to strengthen $\mathrm{NiAl}$ at elevated temperatures. If small $\mathrm{Zr}$ additions are able to provide effective creep resistance in polycrystalline $\mathrm{NiAl}$, then such alloys should be studied with the intention of transferring the strengthening mechanism(s) to more ductile $\mathrm{NiAl}$-based matrices or, alternatively, improving the low-temperature propertics of the strong alloys. 
Table I. Chemistry, Characterization, and Processing Conditions for NiAl Alloys Containing Various Levels of Zr

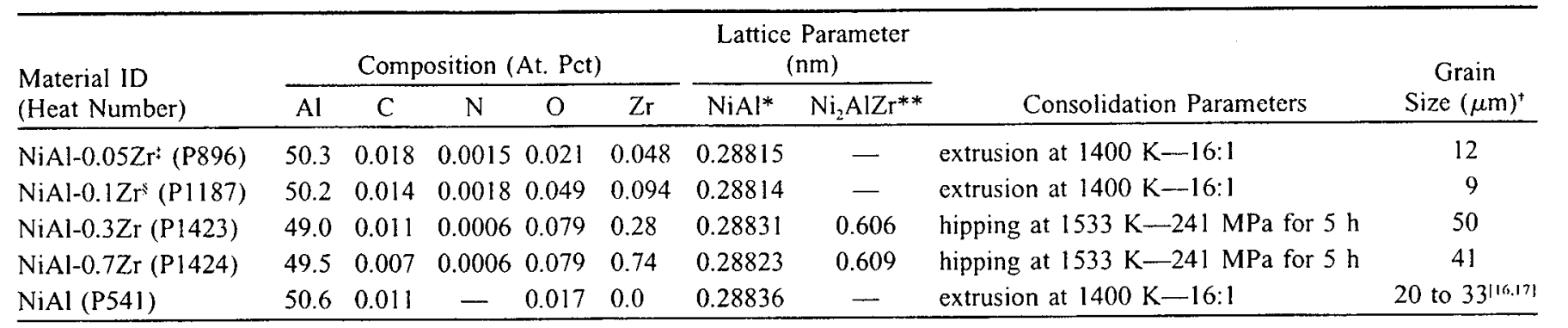

'Standard deviations of $\sim 1 \mu \mathrm{m}$ for $0.05 \mathrm{Zr}$ and $0.1 \mathrm{Zr}$ and $\sim 5 \mu \mathrm{m}$ for $0.3 \mathrm{Zr}$ and $0.7 \mathrm{Zr}$.

$* \pm 0.00004 \mathrm{~nm}$.

$* * \pm 0.002 \mathrm{~nm}$.

:Same lot of powder used in Refs. 16, 17, and 20.

sAlso contains 0.005 at. pct $\mathrm{Hf}$.
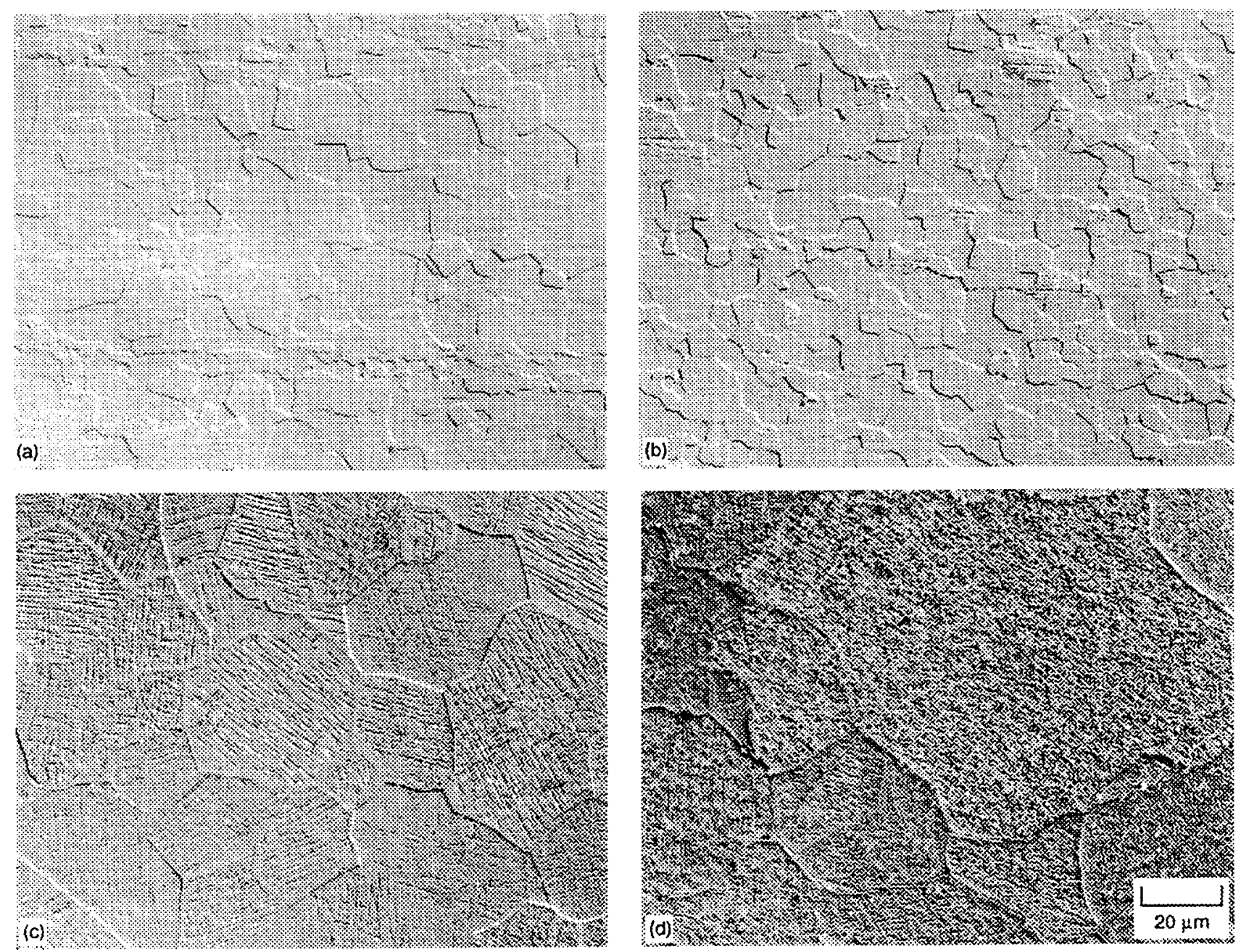

Fig. 1-As-received microstructure of NiAl containing various amounts of $\mathrm{Zr}$ : (a) $0.05 \mathrm{Zr}$, (b) $0.1 \mathrm{Zr},(c) 0.3 \mathrm{Zr}$, and (d) $0.7 \mathrm{Zr}$. The extrusion axis for samples (a) and (b) is horizontal.

In order to determine the ability of minor $\mathrm{Zr}$ alloying additions to provide strength at elevated temperatures, four heats of prealloyed $\mathrm{NiAl}$ containing from 0.05 to 0.7 at. pct $\mathrm{Zr}$ were obtained, consolidated, and compression tested at temperatures between 1000 and $1400 \mathrm{~K}$ at strain rates ranging from about 0.1 to $10^{-9} \mathrm{~s}^{-1}$. In addition, faster strain rate $\left(>10^{-6} \mathrm{~s}^{-1}\right)$ testing of a binary $\mathrm{NiAl}$ between 900 and 1100 $\mathrm{K}$ was undertaken to provide a basis for comparison of strengths at lower temperatures. The results from the mechanical-property testing and its accompanying light optical metallographic studies are documented in this article. 


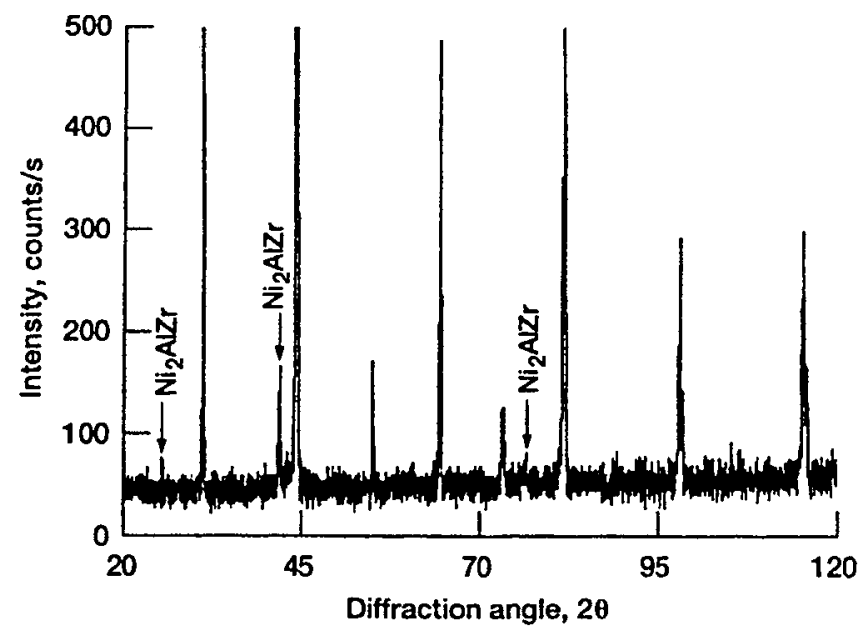

Fig. 2-X-ray diffraction intensity-diffraction angle scan from NiAl$0.7 \mathrm{Zr}$. All peaks not specifically identified as $\mathrm{Ni}_{2} \mathrm{AlZr}$ are from the $\mathrm{NiAl}$ matrix

\section{MATERIALS AND EXPERIMENTAL PROCEDURES}

Four heats of prealloyed $\mathrm{NiAl}+\mathrm{Zr}$ powder were purchased from Homogeneous Metals, Inc., Clayville, New York and sieved to a $-100 /+325$ mesh size (Table I). Approximately $400 \mathrm{~g}$ of powder from each heat were vacuum sealed in 51-mm-diameter mild steel extrusion cans with a $6.3-\mathrm{mm}$ wall thickness. While the 0.05 and $0.1 \mathrm{Zr}$ (all compositions are reported in at. pct) heats were successfully extruded at $1400 \mathrm{~K}$ with $16: 1$ reduction ratio, attempts to densify the 0.3 and $0.7 \mathrm{Zr}$ powders at $16: 1,12: 1$, or $8: 1$ reduction ratios were not successful. Hence, powders from the two higher $\mathrm{Zr}$ content alloys were vacuum sealed in thin-wall, $96-\mathrm{mm}$ diameter by $150-\mathrm{mm}$ long, stainless steel cans, which were subsequently consolidated by hot isostatic pressing ("hipping') at $1533 \mathrm{~K}$ and $241 \mathrm{MPa}$ for 5 hours (Table I).

Typical microstructures of the four materials after densification are presented in Figure 1, which illustrate that all the alloys were fully consolidated after either extrusion (Figures 1(a) and (b)) or hipping (Figures 1(c) and (d)). Measurement of the grain sizes (Table l) revealed that the average dimension for the extruded alloys $(0.05$ and $0.1 \mathrm{Zr})$ was about $10 \mu \mathrm{m}$, which was about a factor of four smaller than that for the hipped materials $(0.3$ and $0.7 \mathrm{Zr})$. Under light optical microscopy conditions, no evidence of second phases could be seen in either of the low $\mathrm{Zr}$-content alloys (Figures 1(a) and (b)); however, clear indications of precipitation were visible in the two higher $\mathrm{Zr}$-containing materials (Figures $1(\mathrm{c})$ and (d)). X-ray diffraction examination of NiAl-0.7Zr (Figure 2, Table I) identified the precipitates as the Heusler-phase $\mathrm{Ni}_{2} \mathrm{AlZr}$ in a $\mathrm{NiAl}$ matrix. Tentative identification of $\mathrm{Ni}_{2} \mathrm{AlZr}$ precipitation was also made for $\mathrm{NiAl}-0.3 \mathrm{Zr}$ based on the appearance of one non-NiAl diffraction peak. The X-ray spectra for both $\mathrm{NiAl}-0.1 \mathrm{Zr}$ and $\mathrm{NiAl}-0.05 \mathrm{Zr}$ were indicative of single-phase, polycrystalline $\mathrm{B} 2$ crystal-structure materials.

The NiAl lattice parameters for all four alloys are consistent with the measured Al levels (Table I), as the lattice parameter values agree with those determined for near-stoichiometric, binary NiAl compositions. ${ }^{[4]}$ In terms of impu- rities, the two higher $\mathrm{Zr}$-content alloys contain much more oxygen than either $\mathrm{NiAl}-0.1 \mathrm{Zr}$ or NiAl-0.05Zr. On the other hand, $\mathrm{NiAl}-0.3 \mathrm{Zr}$ and $\mathrm{NiAl}-0.7 \mathrm{Zr}$ have slightly less carbon and nitrogen then the lower $\mathrm{Zr}$-containing materials. Of these differences, it is probable that some of the oxygen in $\mathrm{NiAl}-0.3 \mathrm{Zr}$ and $\mathrm{NiAl}-0.7 \mathrm{Zr}$ is in the form of $\mathrm{ZrO}_{2}$. Only $\mathrm{NiAl}-0.1 \mathrm{Zr}$ was found to contain any significant substitutional impurity; in this case, about 0.005 pct $\mathrm{Hf}$ was observed (Table I). As Hf is also a Heusler-phase former, the overall effect of this element is to bring the total amount of $\mathrm{Ni}_{2} \mathrm{AlX}$-forming elements to $0.1 \mathrm{pct}$.

Compression samples were fabricated by wire electrodischarge machining (EDM) about $5.5-\mathrm{mm}$ diameter by $\sim 55-\mathrm{mm}$ long cylindrical bars with length parallel to the extrusion axis $(0.05$ and $0.1 \mathrm{Zr})$ or long axis of the hot isostatic press can $(0.3$ and $0.7 \mathrm{Zr})$. After the surface damage from EDM was removed by centerless grinding to a nominally 5-mm diameter, the 55-mm lengths were wire EDM cut into $10-\mathrm{mm}$-long sections. These were then made into true right cylinders by grinding the ends flat and parallel.

The compression specimens were subjected to both constant-velocity and constant-load creep testing in air at temperatures between 1000 and $1400 \mathrm{~K}$. All specimens were tested in the as-consolidated condition. Constant velocity experiments were undertaken in a universal testing machine operating at speeds ranging from $2.1 \mathrm{~mm} / \mathrm{s}$ to $2.1 \times 10^{-1}$ $\mathrm{mm} / \mathrm{s}$, where the samples were loaded between two solid $\mathrm{SiC}$ rams. The autographically recorded load-time charts were converted to true stresses, strains, and strain rates via the offset method and the assumption of conservation of volume. The compressive creep response of the $\mathrm{Zr}$-containing $\mathrm{NiAl}$ specimens was measured by a linear variable differential transducer (LVDT) which monitored the relative positions of the ceramic push bars applying a constant load. The contraction readings were stored in a data-acquisition system as a function of time. Following completion of each creep experiment, the results were normalized with respect to the final specimen length and converted into true stresses and strains by also assuming a constant volume.

As-received and selected post-tested specimens were metallurgically mounted as longitudinal sections, polished, and examined in a light optical microscope in the unetched and etched states. All materials were etched with a solution of $50 \mathrm{ml} \mathrm{HF}, 150 \mathrm{ml} \mathrm{H} \mathrm{H}_{2} \mathrm{O}$ mixed with $100 \mathrm{~g}$ molybdic acid, and usually photographed under differential interference conditions (DIC) to improve grain-boundary definition for grain-size measurements.

\section{RESULTS}

\section{A. Mechanical Properties}

Examples of the true compressive stress-strain curves obtained from constant-velocity testing are presented in Figures 3 through 6 . Behavior of all four materials is shown as a function of nominal strain ratc for 1100 and $1300 \mathrm{~K}$ testing in Figures 3 and 4. These figures illustrate that the strength of the $\mathrm{Zr}$-modified nickel aluminides decreases with decreasing strain rate at all test temperatures. Several general trends were noted. In particular, lower temperature and faster strain rates (Figure 3 ) led to continuous work hardening in all compositions. Also, higher temperature and slower strain rates (Figure 4) generally led to stress-strain 


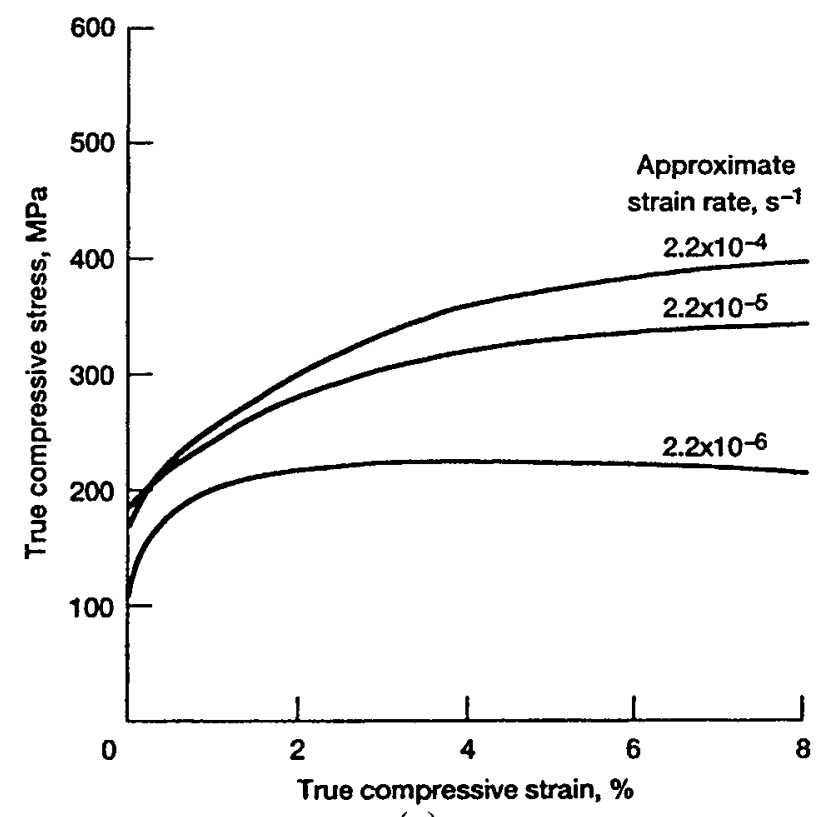

(a)

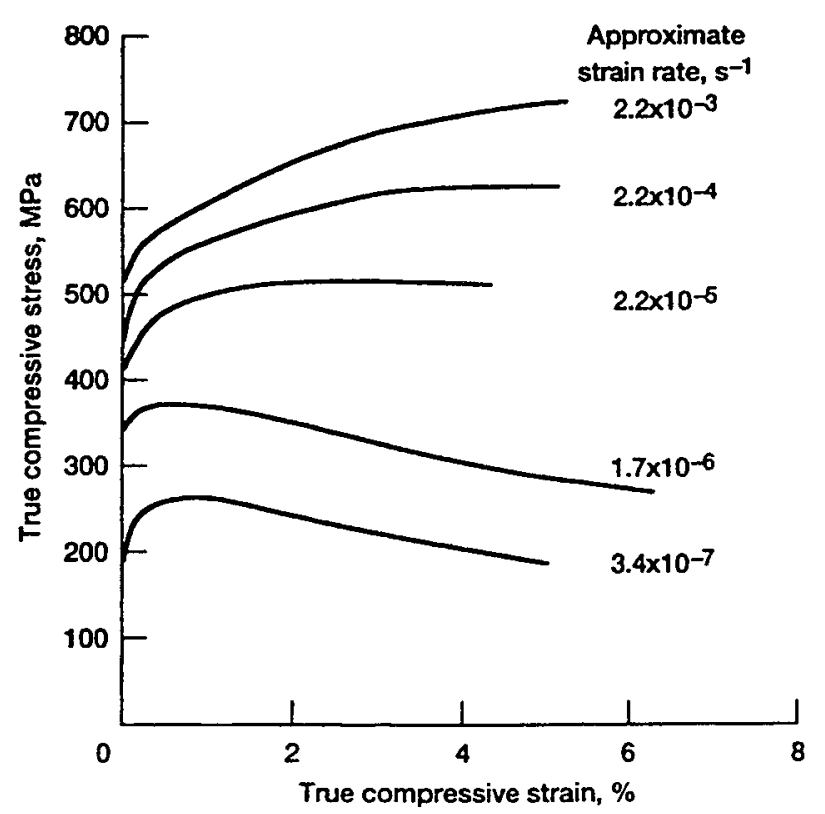

(c)

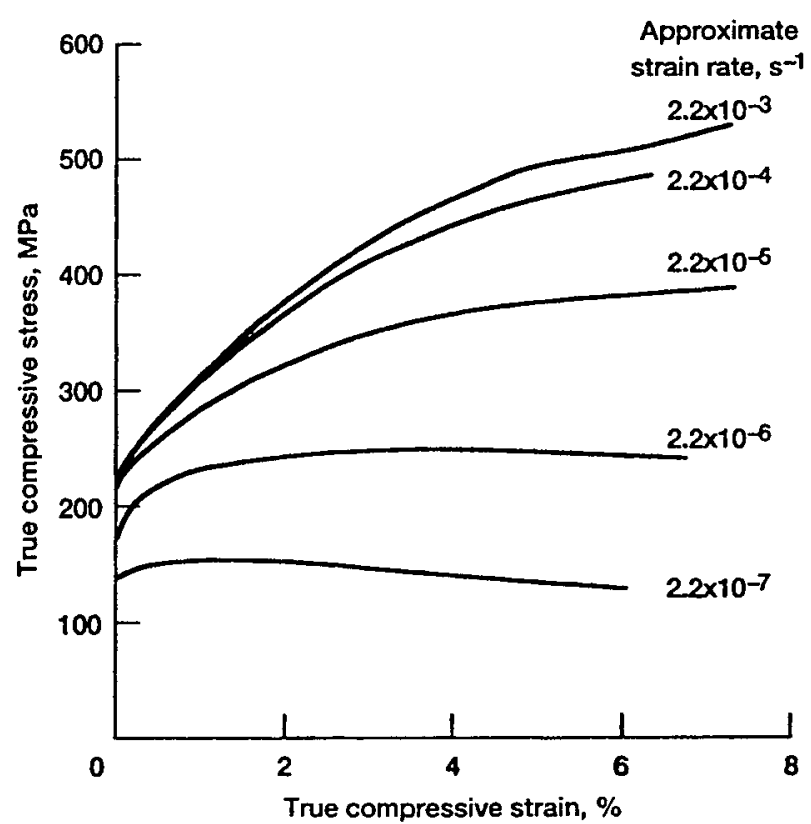

(b)

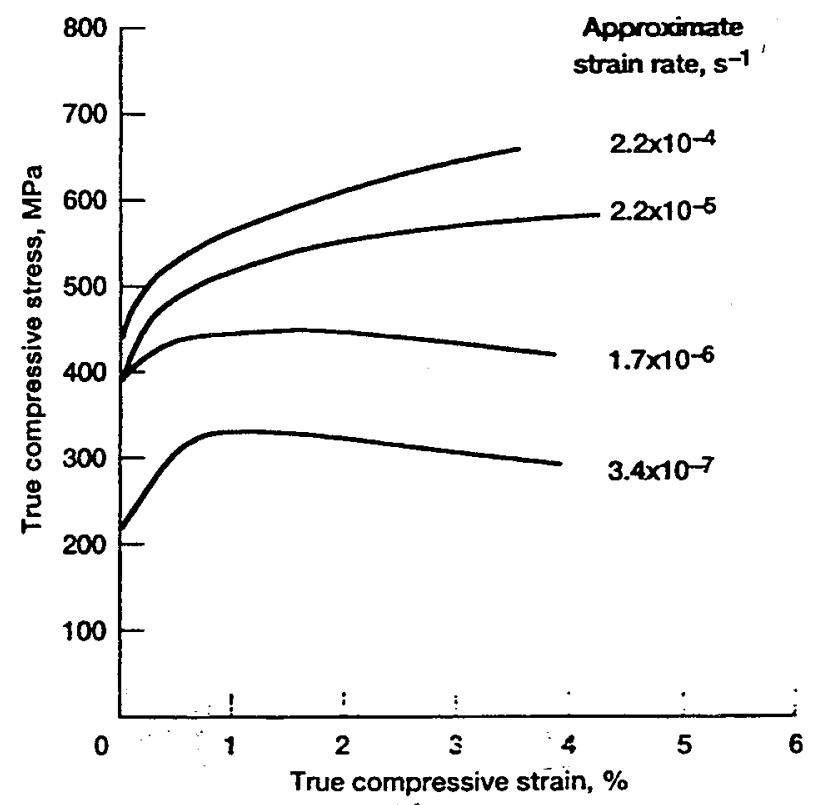

(d)

Fig. 3-True $1100 \mathrm{~K}$ compressive stress-strain curves as a function of strain rate for $\mathrm{NiAl}$ alloys containing $(a) 0.05 \mathrm{Zr},(b)-0.1 \mathrm{Zr},(c) 0.3 \mathrm{Zr}$, and $(d) 0.7 \mathrm{Zr}$.

diagrams with work hardening over the first 1 pct strain followed by continuous flow at a nominally constant stress. Occasionally, examples of work hardening to a maximum stress which was then succeeded by strain softening (Figures 3(c) and (d) and 4(c)) also were seen at all test temperatures.

The effect of $\mathrm{Zr}$ content on elevated-temperature strength is better demonstrated in Figures 5 and 6 for several temperature-strain rate combinations. Figure 5 illustrates the stress-strain behavior for the $\mathrm{NiAl}+\mathrm{Zr}$ alloys at $1200 \mathrm{~K}$ but also is representative of behavior at lower temperatures. At these temperatures for both fast (Figure 5(a)) and slow (Figure 5(b)) strain rates, strength basically increases with increasing $\mathrm{Zr}$ level. This is no longer true for the $\mathrm{Zr}$-containing alloys at and above $1300 \mathrm{~K}$, where at each particular strain rate both the 0.3 and $0.7 \mathrm{Zr}$ alloys have approximately the same strengths (Figure 6). There still exists, however, a distinct difference in strength between simple solid-solution-hardened alloys and the two-phase compositions. This can be directly seen in Figure 6 and through comparison of the $1300 \mathrm{~K}$ stress-strain curves of the 0.05 to $0.1 \mathrm{Zr}$ alloys to those for 0.3 to $0.7 \mathrm{Zr}$ in Figure 5 .

Typical compressive creep curves from the constant-load experiments are presented in Figure 7. All test conditions resulted in a small amount of primary strain followed by steady-state creep and in a few cases apparent tertiary creep. Nine of the ten creep tests were conducted under single-load conditions, while for the tenth sample $(0.7 \mathrm{Zr}-$ $1300 \mathrm{~K}$, Figure $7(\mathrm{~b})$ ), the engineering stress was increased from $20 \mathrm{MPa}$ to $31.2 \mathrm{MPa}$ at $\sim 420 \mathrm{ks}$. For all practical 

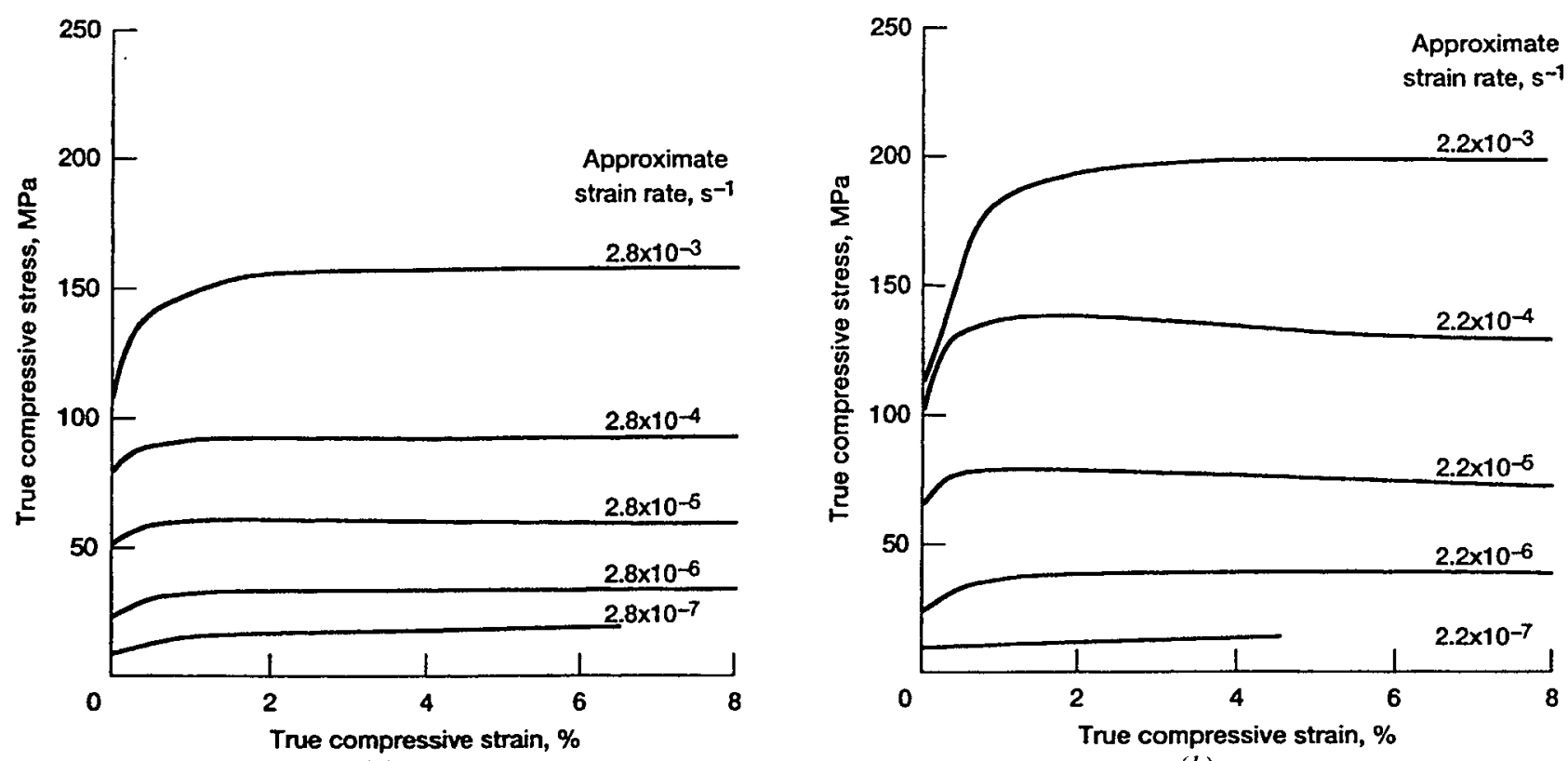

(a)

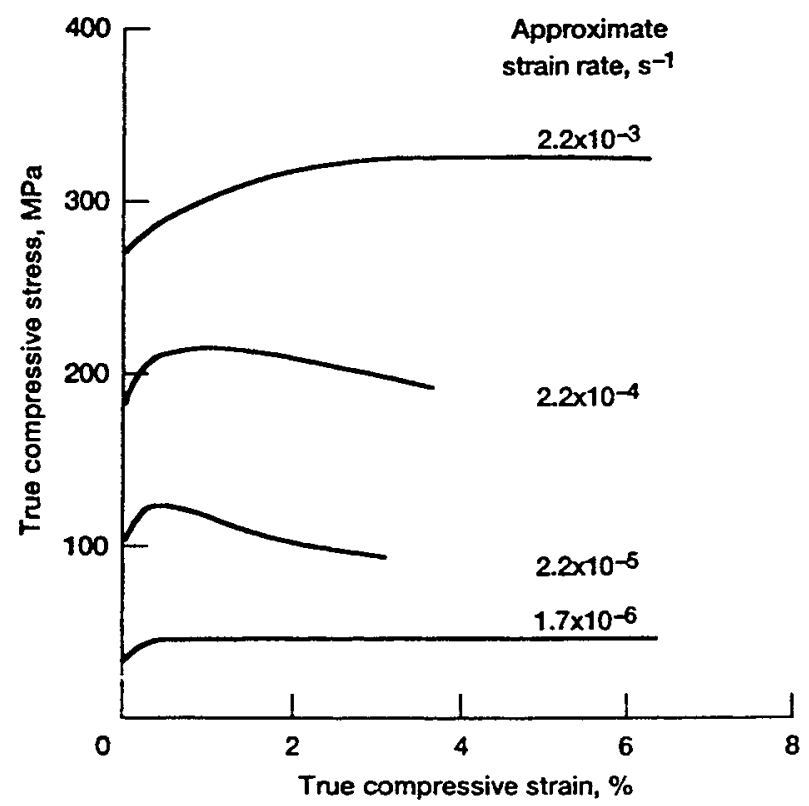

(c)

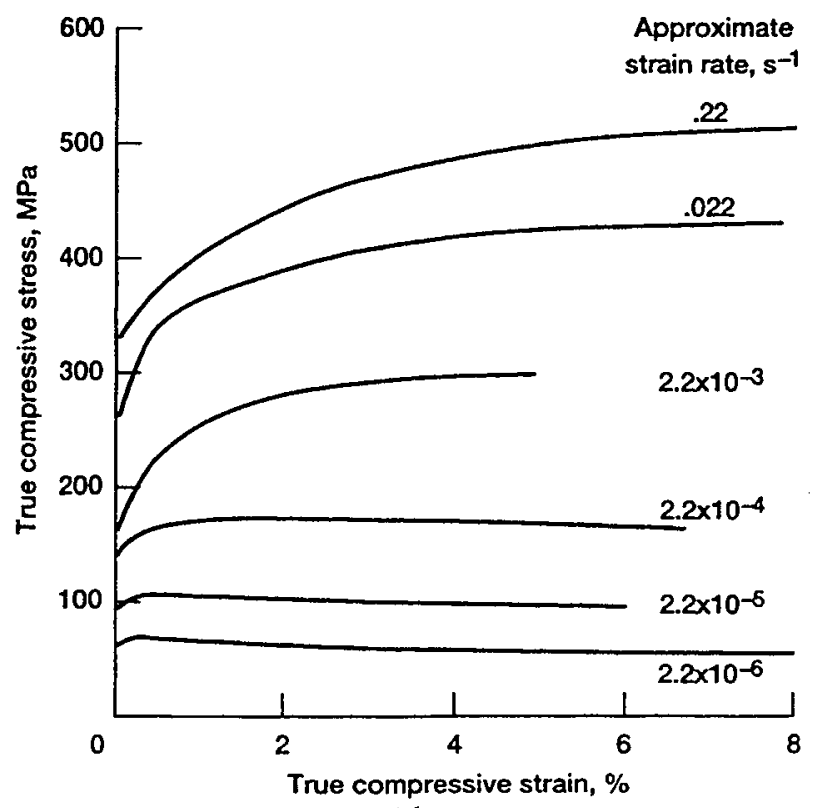

(d)

Fig. 4-True $1300 \mathrm{~K}$ compressive stress-strain curves as a function of strain rate for NiAl alloys containing (a) $0.05 \mathrm{Zr}$, (b) $0.1 \mathrm{Zr},(c) 0.3 \mathrm{Zr}$, and $($ d $) 0.7 \mathrm{Zr}$.

purposes, this stress jump did not result in any transient creep at the higher stress level. It appeared that this specimen was in steady state prior to and immediately following the stress increase.

True compressive flow stress $(\sigma)$-strain rate $(\dot{\varepsilon})$-temperature $(T)$ behavior of the $\mathrm{Zr}$-doped $\mathrm{NiAl}$ alloys is presented in Figure 8, where the flow stress was taken at 3 pct strain from the stress-strain diagrams (Figures 3 through 6) and from the steady-state regime of the creep curves (Figure 7). In addition to the present results, Figure 8(a) also contains some tensile test data (both constant-velocity and constantload creep data) from Bowman and Noebe ${ }^{23.1}$ for the same lot of $\mathrm{NiAl}-0.05 \mathrm{Zr}$. Comparison of the tensile and compressive results for the $0.05 \mathrm{Zr}$ composition reveal little, if any, dependency on the test method or stress direction.
Likewise, the constant-load compression creep results for $0.1 \mathrm{Zr}$ at $1200 \mathrm{~K}$ (Figure $8(\mathrm{~b})$ ) and the 1100 to $1400 \mathrm{~K}$ creep tests of $0.3 \mathrm{Zr}$ (Figure $8(\mathrm{c})$ ) and $0.7 \mathrm{Zr}$ (Figure $8(\mathrm{~d})$ ) are consistent with the constant-velocity data.

Utilizing Figure 8(a) as an example, the $\sigma \dot{-}-T$ properties appear to fall into three regimes: the fastest strain rate/lower temperature data follow a temperature-compensated exponential stress law (Eq. [1]); the slower strain rate/higher temperature data conform to a temperature-compensated power law (Eq. [2]); or, in some cases, the simpler constant-temperature version of Eq. [2].

$$
\begin{aligned}
& \dot{\varepsilon}=A \cdot \exp (\mathrm{C} \sigma) \cdot \exp (-Q / \mathrm{RT}) \\
& \dot{\varepsilon}=B \cdot \sigma^{n} \cdot \exp (-Q / \mathrm{R} T)
\end{aligned}
$$




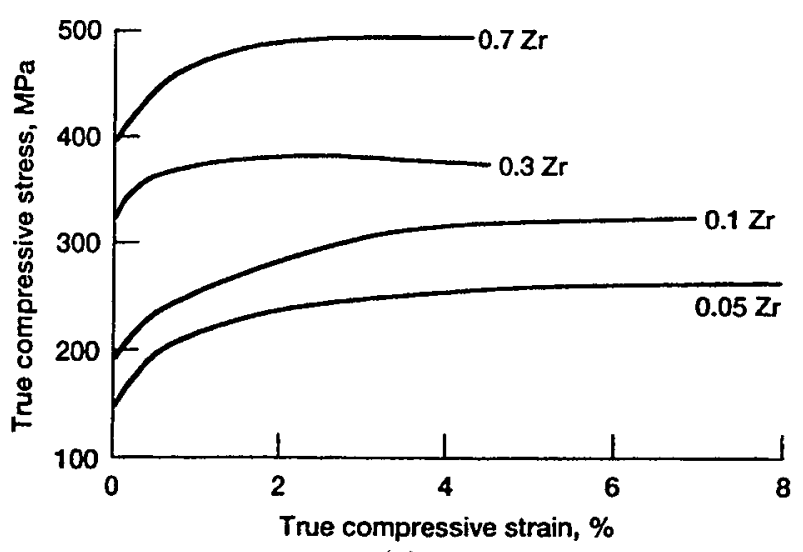

(a)

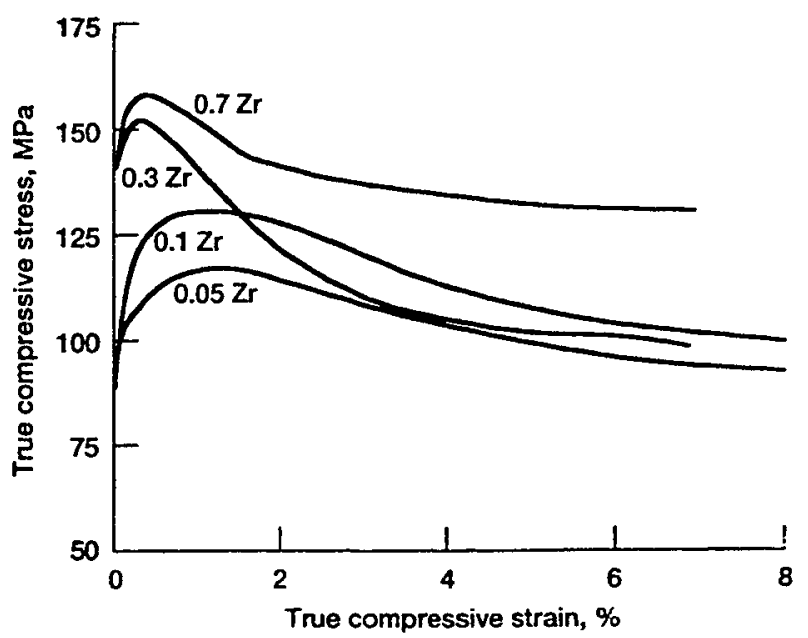

(b)

Fig. 5-True $1200 \mathrm{~K}$ compressive stress-strain curves for several $\mathrm{NiAl}$ alloys containing various amounts of $\mathrm{Zr}$. Tested at a nominal strain rate of (a) $2.2 \times 10^{-4} \mathrm{~s}^{-1}$ and $(b) 2 \times 10^{-4} \mathrm{~s}^{-1}$.

In these equations, $A$ and $B$ are constants, $C$ is the exponential stress constant, $n$ is the stress exponent, $Q$ is the activation energy, and $R$ is the universal gas constant. Suitable groups of data were fitted to Eqs. [1] and [2] by linear regression techniques, and the resultant constants, stress exponents, activation energies, and appropriate statistical parameters, including the standard deviations for the stress constant $\left(\delta_{C}\right)$, stress exponent $\left(\delta_{n}\right)$, activation energy $\left(\delta_{\mathcal{Q}}\right)$, and coefficient of determination $\left(\mathrm{R}_{i}^{2}\right)$, are listed in Table II. Additionally, the curves from the regression analyses are plotted in Figure 8, where the exponential stress fits (Eq. [1]) are shown as dashed lines and the power law fits (Eq. [2]) are represented by solid lines.

All four $\mathrm{Zr}$-containing alloys possessed clearly defined temperature-stress regimes (Figure 8 ), where the temperature-compensated exponential law (Eq. [1]) was the appropriate descriptive equation. Application of the temperature-compensated power law (Eq. (2)), however, required some judgment. In particular, examination of the data for both solid-solution alloys (Figures 8(a) and (b)) strongly suggested that the stress exponent for the highest test temperature was different than that for the lower temperatures. Hence, the $1300 \mathrm{~K}$ results for NiAl-0.05Zr (Figure $8(\mathrm{a})$ ) and the $1400 \mathrm{~K}$ data for NiAl-0.1Zr (Figure $8(\mathrm{~b})$ ) were fitted with the constant-temperature version of Eq. [2],

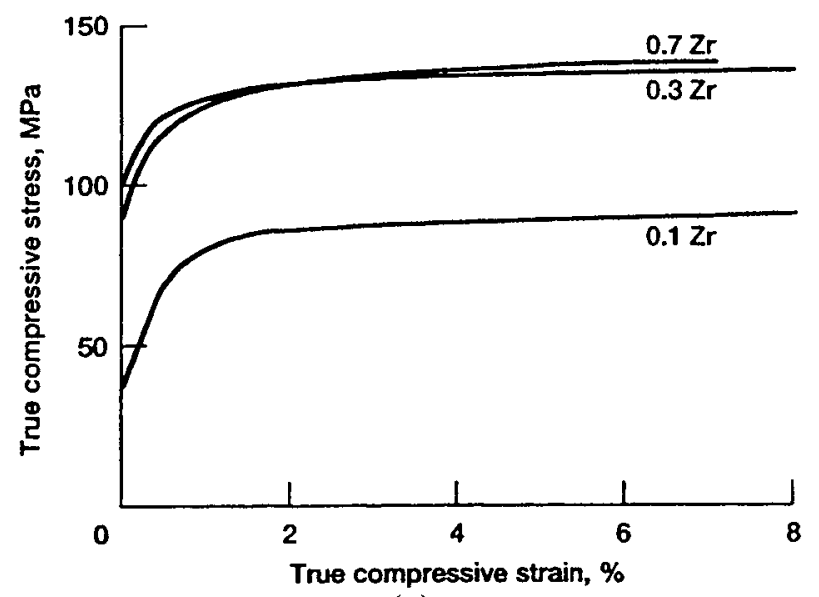

(a)

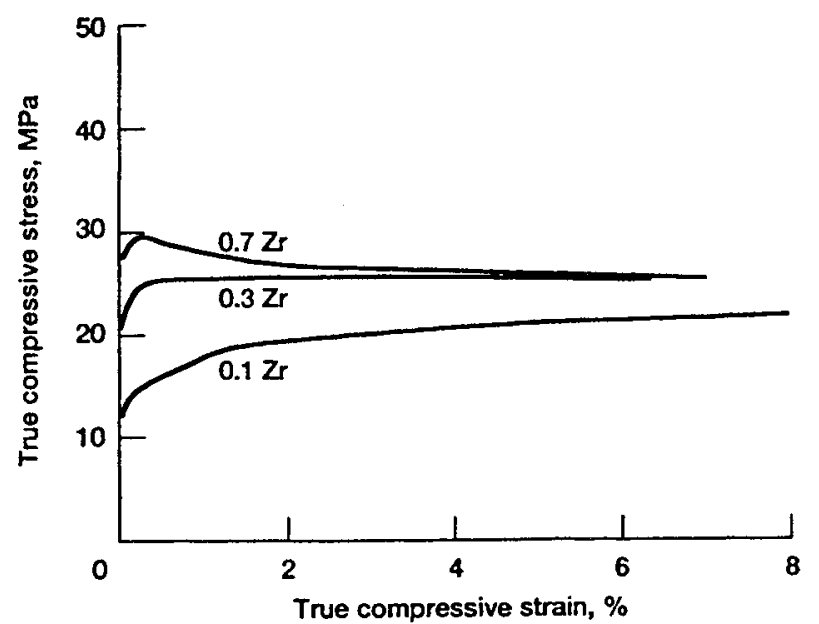

(b)

Fig. 6-True $1400 \mathrm{~K}$ compressive stress-strain curves for several NiAl alloys containing various amounts of $\mathrm{Zr}$. Tested at a nominal strain rate of $(a) 2.2 \times 10^{-1} \mathrm{~s}^{-1}$ and $(b) 2 \times 10^{-6} \mathrm{~s}^{-1}$.

while the lower-temperature data were simultaneously fitted as functions of temperature and stress. A similar change in deformation behavior was not observed for either the NiAl$0.3 \mathrm{Zr}$ (Figure $8(\mathrm{c})$ ) or $\mathrm{NiAl}-0.7 \mathrm{Zr}$ (Figure $8(\mathrm{~d})$ ). Instead, Eq. [2] was applicable over all test temperatures for the two Heusler-containing alloys.

Both visually in Figure 8 and by the coefficient of determination in Table II, it can be seen that Eqs. [1] and [2] fit the experimental data reasonably well. The regimes of $\sigma \dot{\boldsymbol{E}}-T$ data currently described by the temperature-compensated exponential stress law in Figure 8 were also fitted to Eq. [2]; however, in each instance, the temperature-compensated power law analysis resulted in a poorer fit (Table II).

\section{B. Post-Test Microstructures}

Following compression testing, a number of samples were examined by light optical metallography techniques to assess changes in the microstructure. In the unetched condition, it was clear that the $\mathrm{Zr}$-modified alloys were susceptible to internal oxidation with the degree of attack increasing with increasing $\mathrm{Zr}$ content. Overall, shorter term/lower temperature testing did not produce any damage, but longer term/higher temperature conditions led to 


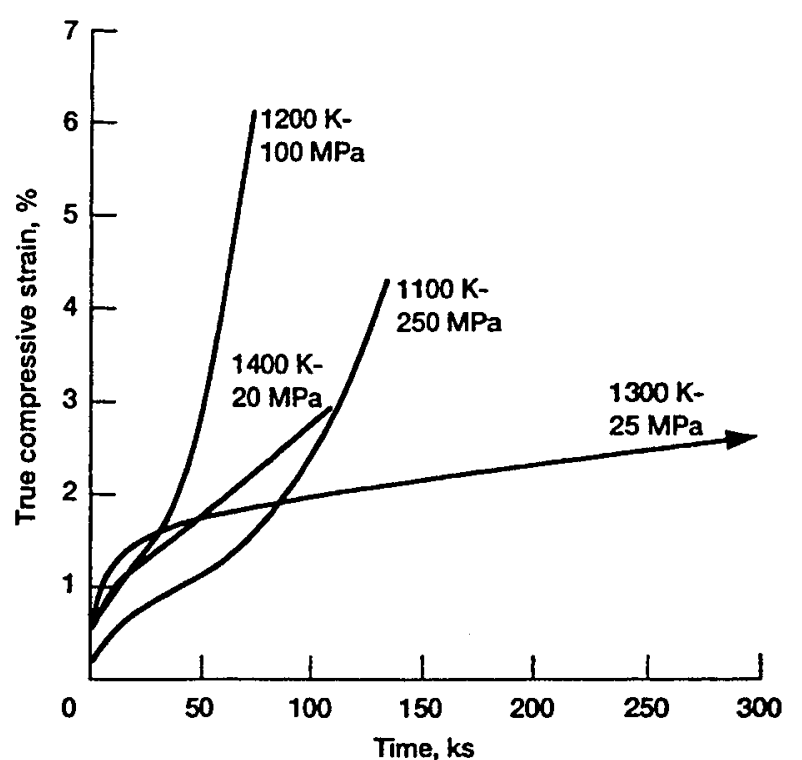

(a)

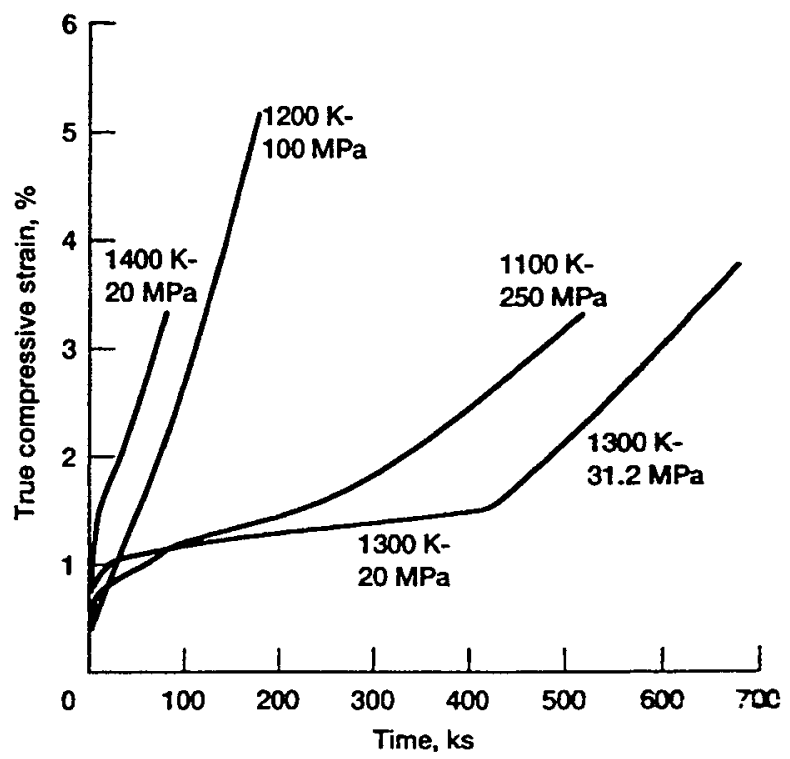

(b)

Fig. 7-True compressive creep curves for (a) $0.3 \mathrm{Zr}$ and (b) $0.7 \mathrm{Zr}$ NiAlbased alloys tested under a variety of conditions.

visible attack. Some examples of this behavior can be seen in Figure 9 for test specimens subjected to the highest temperature, longest term constant-velocity conditions. Minor intergranular oxidation was noted in $0.05 \mathrm{Zr}$ after very slow compression testing at $1300 \mathrm{~K}$ (Figure $9(\mathrm{a}))$ and $1200 \mathrm{~K}$. Similar structures were also found in $0.1 \mathrm{Zr}$ after overnight testing at $1400 \mathrm{~K}$ (Figure $9(\mathrm{~b})$ ) and a 5-day experiment at $1300 \mathrm{~K}$ at $-2 \times 10^{-7} \mathrm{~s}^{-1}$. Little attack was seen in $0.1 \mathrm{Zr}$ following long-term $1200 \mathrm{~K}$ testing. Relatively severe internal oxidation, to a depth of about $100 \mu \mathrm{m}$, took place in both the $0.3 \mathrm{Zr}$ (Figure 9(c)) and $0.7 \mathrm{Zr}$ (Figure 9(d)) after being compressed for about 18 hours at $\sim 2 \times 10^{-6} \mathrm{~s}^{-1}$ and $1400 \mathrm{~K}$. Reduction of the temperature to $1300 \mathrm{~K}$ did not diminish the degree of attack in overnight testing of $0.7 \mathrm{Zr}$; however, only minor intergranular oxidation occurred in $0.3 \mathrm{Zr}$ compressed under similar conditions. Neither of these two-phase alloys exhibited any grain-boundary oxidation after $1200 \mathrm{~K}$ testing.

In general, little microstructural damage in terms of the formation of internal cracks or pores was seen in any tested samples; however, some short transverse and/or intergranular cracking was found near the specimen surfaces after fast strain rate/lower temperature testing of all alloys. Evaluation of the post-test grain sizes after a variety of test conditions (Table III) revealed little change from the asreceived values (Table I). The only exceptions being the two solid-solution alloys after their severest (longest term, highest temperature) testing, where some grain growth appeared to take place.

\section{DISCUSSION}

\section{A. Zr for Effective Strengthening}

The primary purpose of this work was to determine if polycrystalline $\mathrm{Zr}$-modified $\mathrm{NiAl}$ possessed any significant elevated-temperature strength advantage over binary nickel aluminide. Comparison of the flow stress-strain rate behavior of the $\mathrm{Zr}$-modified alloys to $\mathrm{NiAl}$ is presented in Figure 10. Because little $\dot{\varepsilon}-\sigma$ data exists for binary $\mathrm{NiAl}$ at faster strain rates $\left(\dot{\varepsilon} \geq 10^{-5} \mathrm{~s}^{-1}\right)$ at and below $1100 \mathrm{~K}$, constantvelocity testing of extruded $\mathrm{Ni}-50.6 \mathrm{Al}$ was undertaken between 900 and $1100 \mathrm{~K}$. The results of this testing are reported in Appendix A and the appropriate data are utilized in Figure 10.

It is explicit in Figure 10 that $\mathrm{Zr}$ additions to $\mathrm{NiAl}$ promote significant strengthening at 1000 and $1100 \mathrm{~K}$ (Figures 10 (a) and (b)); for example, the strength of NiAl-0.7Zr is eightfold that of binary NiAl. Furthermore, this advantage is maintained to very low strain rates at these two temperatures. At $1200 \mathrm{~K}$ (Figure $10(\mathrm{c})$ ), however, the superior deformation resistance of $\mathrm{NiAl}$ alloyed with $\mathrm{Zr}$ begins to abate. The existing data demonstrate, for instance, that the strength advantage of $\mathrm{NiAl}-0.05 \mathrm{Zr}$ over $\mathrm{NiAl}$ at higher strain rates $\left(>10^{-5} \mathrm{~s}^{-1}\right)$ lessens as the deformation rates decrease. With another $100 \mathrm{~K}$ increase in temperature, the relative advantage of the $\mathrm{Zr}$ additions is further diminished, whereas at $1300 \mathrm{~K}$ (Figure 10 (d)) $\mathrm{NiAl}-0.7 \mathrm{Zr}$ is only about three times stronger than $\mathrm{NiAl}$ in comparison to the factor of 8 increase at $1100 \mathrm{~K}$ (Figure $10(\mathrm{~b})$ ). Last, it can be seen at $1400 \mathrm{~K}$ (Figure $10(\mathrm{e})$ ) that the strength advantage of the $\mathrm{Zr}$-modified alloys is, at best, a factor of 2. For example, at a strain rate of $10^{-5} \mathrm{~s}^{-1}$, the flow stress for NiAl$0.3 / 0.7 \mathrm{Zr}$ is $\sim 40 \mathrm{MPa}$ compared to $\sim 20 \mathrm{MPa}$ for binary $\mathrm{NiAl}$. Also, it can be envisioned via extrapolation of the current $1400 \mathrm{~K}$ data that all the $\mathrm{Zr}$-modified alloys and binary $\mathrm{NiAl}$ will have nearly equal strengths at a strain rate of about $10^{-8} \mathrm{~s}^{-1}$.

In terms of the relationship between strength and $\mathrm{Zr}$ content, the results in Figure 10 clearly indicate that the twophase alloys $(0.3$ and $0.7 \mathrm{Zr})$ are stronger than the single-phase compositions $(0.05$ and $0.1 \mathrm{Zr})$ and binary $\mathrm{NiAl}$ under all current test conditions. However, strength does not always scale in direct proportion with increasing $\mathrm{Zr}$ level. In general, increasing temperatures or decreasing strain rate diminish the importance of $\mathrm{Zr}$. Certainly at 1100 $\mathrm{K}$ (Figure $10(\mathrm{~b})$ ), and presumably also at $1000 \mathrm{~K}$ (Figure 10(a)), strength at all strain rates increases with increasing 

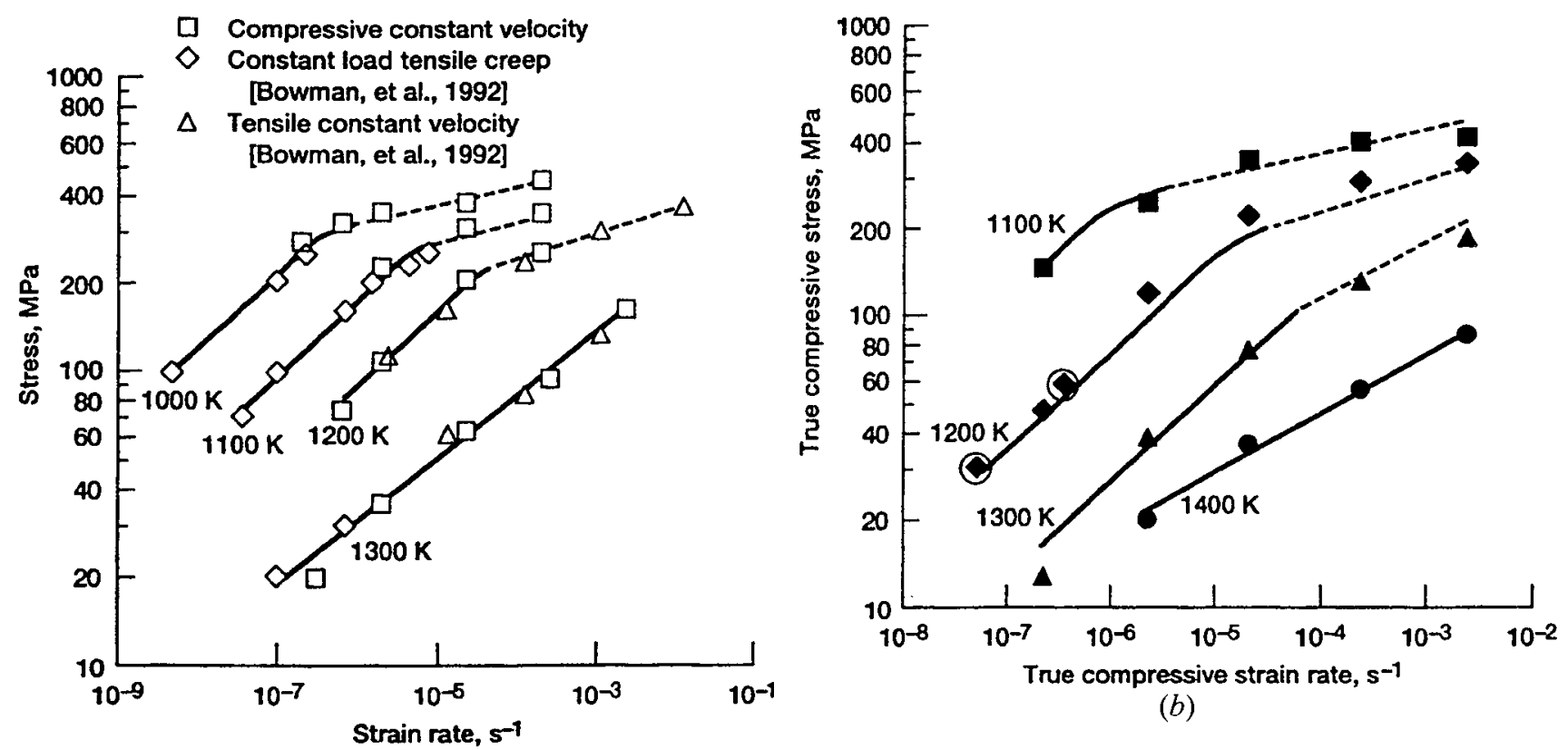

(a)

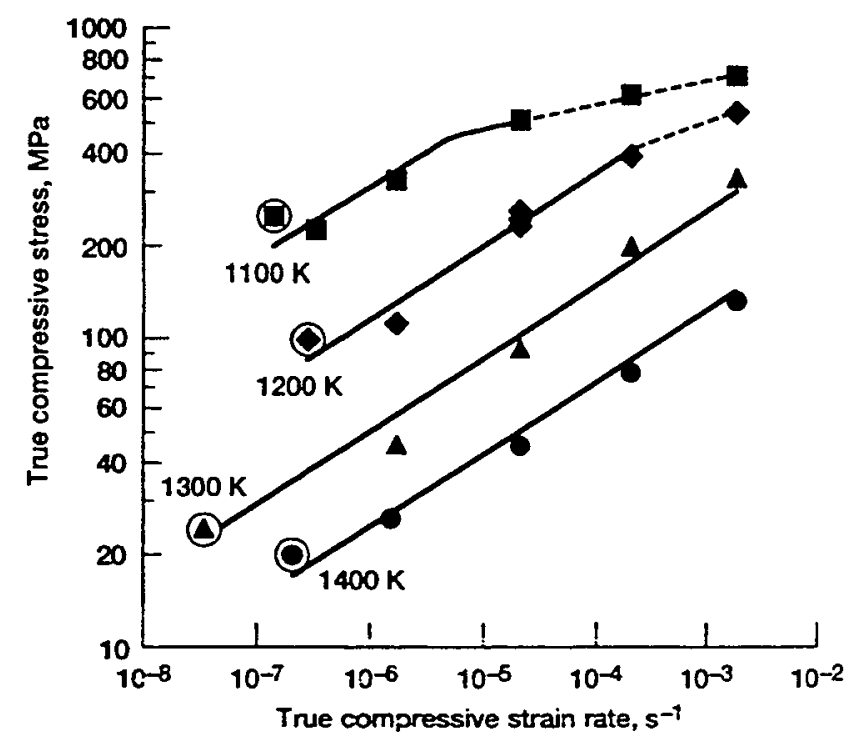

(c)

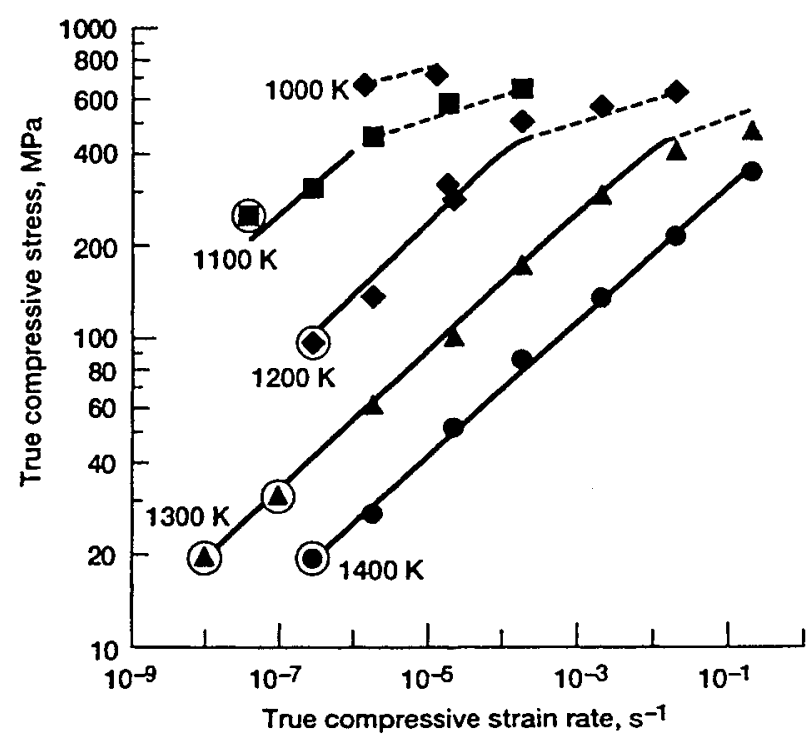

(d)

Fig. 8-True flow stress-strain rate behavior for $\mathrm{NiAl}$ alloys containing $(a) 0.05 \mathrm{Zr},(b) 0.1 \mathrm{Zr},(c) 0.3 \mathrm{Zr}$, and $(d) 0.7 \mathrm{Zr}$. Tensile results in (a) are from Ref. 23. Constant load compressive creep data points for $(b) 0.1 \mathrm{Zr},(c) 0.3 \mathrm{Zr}$, and $(d) 0.7 \mathrm{Zr}$ are encircled.

$\mathrm{Zr}$ content. But at $1200 \mathrm{~K}$ (Figure $10(\mathrm{c})$ ), the two solidsolution alloys have similar strengths, while both two-phase alloys continue to order as their $\mathrm{Zr}$ content. At 1300 and $1400 \mathrm{~K}$ (Figures $10(\mathrm{~d})$ and (e)), the 0.3 and $0.7 \mathrm{Zr}$ alloys demonstrate about the same resistance to deformation which is, in turn, somewhat better than the single-phase materials. Compared to the $1200 \mathrm{~K}$ results (Figure $10(\mathrm{c})$ ), behavior of the 0.05 and $0.1 \mathrm{Zr}$ alloys at $1300 \mathrm{~K}$ (Figure $10(\mathrm{~d}))$ is anomalous. In addition to the reemergence of the strength of $0.1 \mathrm{Zr}$ over $0.05 \mathrm{Zr}$ at fast strain rates, $1300 \mathrm{~K}$ testing also produced the situation where at $\sim 2 \times 10^{-7} \mathrm{~s}^{-1}$, the flow stress of $\mathrm{NiAl}-0.1 \mathrm{Zr}$ was less than that for $\mathrm{NiAl}$ $0.05 \mathrm{Zr}$ or even $\mathrm{NiAl}$. Because the grain size of $\mathrm{NiAl}-0.1 \mathrm{Zr}$ remained small $(\sim 10 \mu \mathrm{m})$ while that of $\mathrm{NiAl}-0.05 \mathrm{Zr}$ increased to $17 \mu \mathrm{m}$ (Table III), it is likely that the low strength of $\mathrm{NiAl}-0.1 \mathrm{Zr}$ at $1300 \mathrm{~K}$ and $\sim 10^{-7} \mathrm{~s}^{-1}$ is due to an increasing contribution from grain-boundary deformation mechanisms similar to those observed in $\mathrm{NiAl} .^{[26,27]}$

The data in Figure 10, taken as a whole, demonstrate that $\mathrm{Zr}$ additions up to $0.7 \mathrm{pct}$ in polycrystalline $\mathrm{NiAl}$ will not produce a significant improvement in creep behavior if applications at very high temperatures and slower strain rates are the objective. On the other hand, $\mathrm{Zr}$ can be quite advantageous for lower temperature deformation resistance. For example, at $1100 \mathrm{~K}$ (Figure $10(\mathrm{~b})$ ), even as little as $0.05 \mathrm{Zr}$ produces a large relative strengthening. However, to produce meaningful strength levels over a broader range of temperatures and strain rates, it appears that a distribution of $\mathrm{Ni}_{2} \mathrm{AlZr}$ precipitates will be necessary. Thus, $\mathrm{Zr}$ concentrations greater than $0.1 \mathrm{pct}$ will be required. However, the 
Table II. Temperature-Compensated Exponential Law, Temperature-Compensated Power Law, and Power-Law Fits of the Flow Stress-Strain Rate Data for NiAl Alloys Containing Various Amounts of $\mathrm{Zr}$

(a) Temperature-Compensated Exponential Law Analysis

\begin{tabular}{lcccccccc}
\hline \multicolumn{1}{c}{ Material } & $\begin{array}{c}\text { Number of } \\
\text { Data Points }\end{array}$ & $\begin{array}{c}\text { Temperature } \\
\text { Range }(\mathrm{K})\end{array}$ & $A\left(\mathrm{~s}^{-1}\right)$ & $C(\mathrm{MPa})^{-1}$ & $Q(\mathrm{~kJ} / \mathrm{mol})$ & $R_{d i}{ }^{2}$ & $\delta_{c}$ & $\delta_{Q}(\mathrm{~kJ} / \mathrm{mol})$ \\
\hline $\mathrm{NiAl}-0.05 \mathrm{Zr}$ & 12 & 1000 to 1200 & $9.97 \times 10^{\times}$ & 0.0451 & 405 & 0.935 & 0.0052 \\
$\mathrm{NiAl}-0.1 \mathrm{Zr}$ & 9 & 1100 to 1300 & $5.17 \times 10^{14}$ & 0.0314 & 505 & 0.864 & 0.0056 & 75.9 \\
$\mathrm{NiAl}-0.3 \mathrm{Zr}$ & 5 & 1100 to 1200 & $7.26 \times 10^{12}$ & 0.0214 & 467 & 0.928 & 0.0045 & 102.3 \\
$\mathrm{NiAl}-0.7 \mathrm{Zr}$ & 8 & 1000 to 1200 & $1.97 \times 10^{15}$ & 0.0239 & 538 & 0.935 & 0.0055 & 57.2 \\
$\mathrm{NiAl}$ & 12 & 900 to 1100 & $1.40 \times 10^{4}$ & 0.187 & 317 & 0.917 & 0.020 \\
\hline
\end{tabular}

(b) Temperature-Compensated Power-Law Analysis

\begin{tabular}{lcccccccc}
\hline \multicolumn{1}{c}{ Material } & $\begin{array}{c}\text { Number of } \\
\text { Data Points }\end{array}$ & $\begin{array}{c}\text { Temperature } \\
\text { Range }(\mathrm{K})\end{array}$ & $B\left(\mathrm{~s}^{-1}\right)$ & $n$ & $Q(\mathrm{~kJ} / \mathrm{mol})$ & $R_{d}^{2}$ & $\delta_{n}$ & $\delta_{Q}(\mathrm{~kJ} / \mathrm{mol})$ \\
\hline NiAl-0.05Zr & 17 & 1000 to 1200 & $9.03 \times 10^{-2}$ & 4.00 & 292 & 0.985 & 0.17 \\
NiAl-0.1Zr & 11 & 1100 to 1300 & $2.88 \times 10^{5}$ & 2.97 & 391 & 0.967 & 0.21 \\
NiAl-0.3Zr & 20 & 1100 to 1400 & $3.69 \times 10^{5}$ & 4.33 & 471 & 0.970 & 0.19 & 30.7 \\
NiAl-0.7Zr & 22 & 1100 to 1400 & $2.38 \times 10^{\text {* }}$ & 4.57 & 555 & 0.993 & 0.10 & 12.6 \\
NiAll201 & 73 & 1100 to 1400 & 0.16 & 5.75 & 314 & 0.990 & 0.05 \\
\hline
\end{tabular}

(c) Power-Law Analysis

\begin{tabular}{lcccccc}
\hline Material & $\begin{array}{c}\text { Number of } \\
\text { Data Points }\end{array}$ & $\begin{array}{c}\text { Temperature } \\
(\mathrm{K})\end{array}$ & $B\left(\mathrm{~s}^{-1}\right)$ & $n$ & $R_{t^{2}}$ & $\delta_{n}$ \\
\hline $\mathrm{NiAl}-0.05 \mathrm{Zr}$ & 10 & 1300 & $7.76 \times 10^{-14}$ & 4.79 & 0.988 & 0.19 \\
$\mathrm{NiAl}-0.1 \mathrm{Zr}$ & 4 & 1400 & $1.05 \times 10^{-12}$ & 4.76 & 0.993 & 0.28 \\
$\mathrm{Ni}-49.2 \mathrm{Al} l^{124}$ & 3 & 1000 & $2.23 \times 10^{-11}$ & 6.85 & 0.999 & 0.18 \\
\hline
\end{tabular}

current results (Figure 10) indicate that no real strength advantage exists for $\mathrm{Zr}$ contents above $0.3 \mathrm{pct}$, and the degree of damage from $1400 \mathrm{~K}$ oxidation suggests that an increase from 0.3 pct $\mathrm{Zr}$ (Figure $9(\mathrm{c})$ ) to 0.7 pct $\mathrm{Zr}$ (Figure 9(d)) probably leads to a lowered environmental resistance due to internal oxidation. In view of the relatively minor oxidative attack in the 0.1 pct Zr alloy (Figure 9(b)) compared to the 0.3 pet $\mathrm{Zr}$ version (Figure $9(\mathrm{c})$ ) after similar $1400 \mathrm{~K}$ testing as well as the near equivalence of elevated-temperature strength for the current two Heusler-strengthened materials, alloys with $\mathrm{Zr}$ contents between 0.1 and 0.3 pct should possess the optimum properties and would be worthy of further investigation.

Finally, it should be noted once again that both of the present two-phase alloys were tested in the as-hipped condition (1533 K-241 MPa-5 hours). If two-phase systems are the best choice for improving the mechanical strength at and below $1200 \mathrm{~K}$, then heat-treatment studies that affect the precipitate size and distribution should be undertaken. Through analogy with $\gamma^{\prime}$-strengthened Ni-base alloys, it is possible that the intermediate temperature strength of polycrystalline $\mathrm{NiAl}-\mathrm{Ni}_{2} \mathrm{AlZr}$ alloys can be significantly increased above current levels by appropriate heat treatments, perhaps combined with further alloying additions.

\section{B. Deformation Mechanisms in Zr-Modified NiAl}

The present study indicates that the $\mathrm{Zr}$-modified materials are consistently stronger than binary $\mathrm{NiAl}$ and that the two-phase systems demonstrate real potential for intermediate temperature applications. Possible reasons for the increased strength of the $\mathrm{Zr}$-modified alloys over binary $\mathrm{NiAl}$ can be found in the magnitudes of the deformation parameters listed in Table II. In particular, the activation energies from the temperature-compensated power law regime (Table II(b)) for the four $\mathrm{Zr}$-modified alloys generally increase with increasing $\mathrm{Zr}$ content. This trend indicates that thermally activated deformation is becoming more difficult as the amount of $\mathrm{Zr}$ is increased. Such behavior could bc partly due to a changing dislocation deformation mechanism as reflected in the stress exponents.

Creep in polycrystalline NiAl containing from 44 to 50.6 $\mathrm{Al}$ is dislocation climb controlled between 1100 and 1400 $K$, involving the formation of subgrains, ${ }^{[24]}$ and this results in a stress exponent of about 5.8 (Table Il(b)). Upon the addition of very small amounts of $\mathrm{Zr}$ to $\mathrm{NiAl}$, dramatic decreases in the stress exponents are observed in both single-phase alloys at lower test temperatures: $n=4$ for NiAl$0.05 \mathrm{Zr}$ between 1000 and $1200 \mathrm{~K}$ and $n=3$ for $\mathrm{NiAl}-0.1 \mathrm{Zr}$ between 1100 and $1300 \mathrm{~K}$ (Table II(b)). In general, such stress exponents are indicative of a transition from climbcontrolled creep to a viscous glide creep mechanism where the maintenance of an atmosphere of solute atoms around a dislocation inhibits its motion. At higher temperatures, however, both alloys demonstrate an apparent change to a higher stress exponent, where $n$ is 4.8 for both $\mathrm{NiAl}-0.05 \mathrm{Zr}$ at $1300 \mathrm{~K}$ and $\mathrm{NiAl}-0.1 \mathrm{Zr}$ at $1400 \mathrm{~K}$ (Table II(c)). Thus, it appears that $\mathrm{NiAl}-\mathrm{Zr}$ solid solutions undergo a class $\mathrm{M}$ to class A transition in creep mechanism (a change in stress exponent from about 5 to 3 ), as discussed by Langdon ${ }^{[28]}$ for a number of metallic solid solutions.

Raj et al. ${ }^{[29]}$ have studied deformation of the single-phase B2 alloy Ni-30Al-20Fe-0.05Zr between 1073 and $1300 \mathrm{~K}$, and they observed a similar transition in stress exponent to that found in the 0.05 and $0.1 \mathrm{Zr}$-modified nickel alumin- 

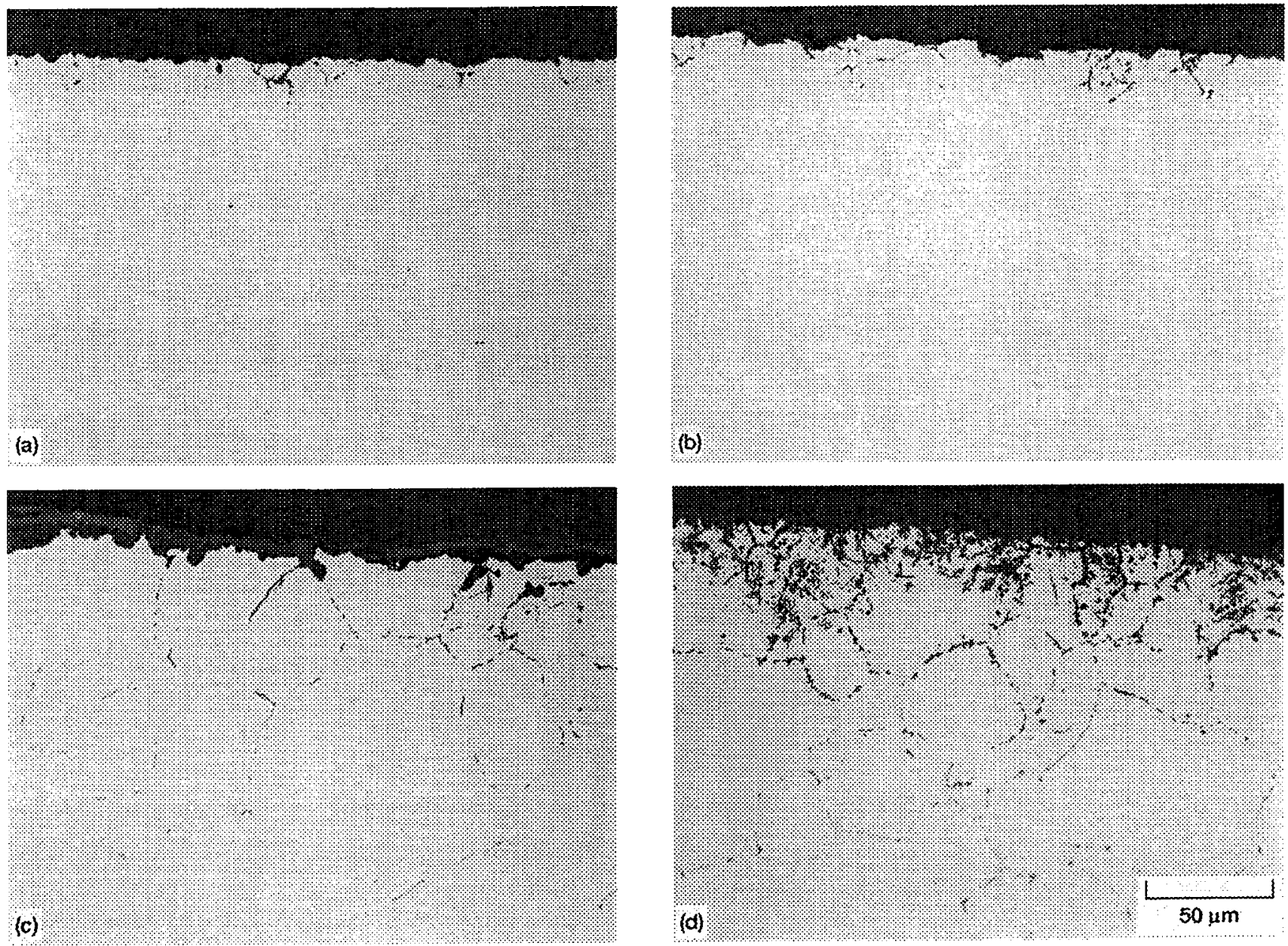

Fig. 9-Unetched near-surface microstructure of compression-tested $\mathrm{Zr}$-modified NiAl. (a) $0.05 \mathrm{Zr}$ tested at $1300 \mathrm{~K}$ at $2.2 \times 10^{-7} \mathrm{~s}^{-1}$ to 6.5 pct strain, $(b)$ $0.1 \mathrm{Zr}$ tested at $1400 \mathrm{~K}$ at $2.2 \times 10^{-6} \mathrm{~s}^{-1}$ to $8.5 \mathrm{pct}$ strain, (c) $0.3 \mathrm{Zr}$ tested at $1400 \mathrm{~K}$ at $1.5 \times 10^{-6} \mathrm{~s}^{-1}$ to $6.4 \mathrm{pct}$ strain, and $(d) 0.7 \mathrm{Zr}$ tested at $1400 \mathrm{~K}$ at $1.7 \times 10^{-6} \mathrm{~s}^{-1}$ to 7.0 pct strain.

Table III. Post-Test Average Grain Dimensions for NiAl Alloys Containing Various Amounts of $\mathrm{Zr}$

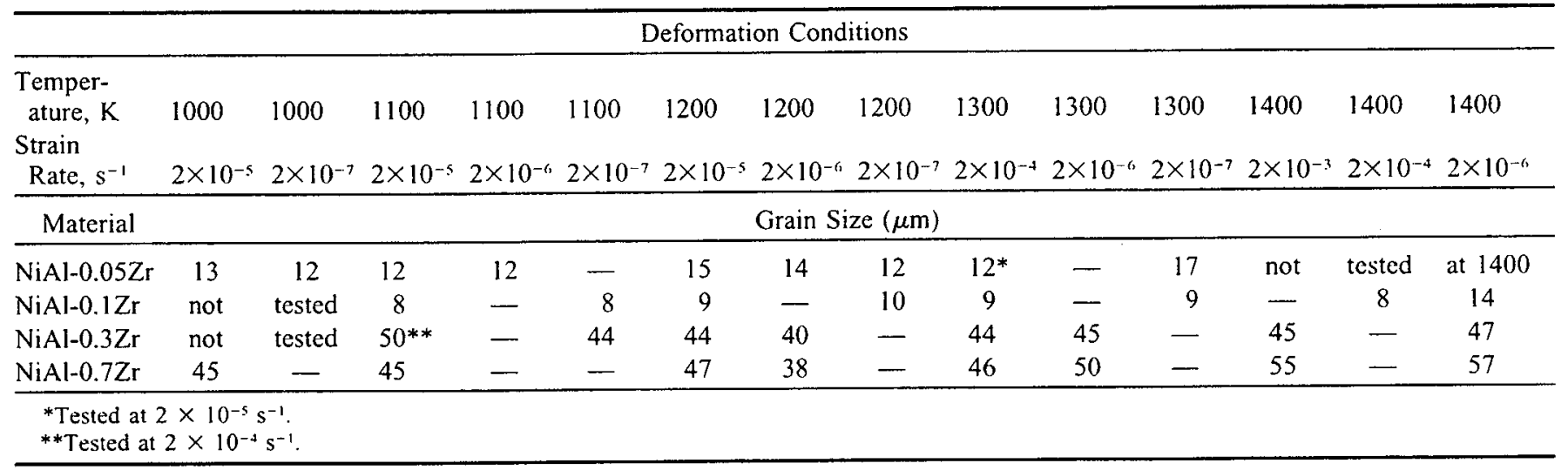

ides. Specifically, they reported two different power law stress exponent regimes (Table IV). Their $1073 \mathrm{~K}$ and faster $1200 \mathrm{~K}$ flow stress-strain rate results could be best described by an $n$ of $\sim 2.5$, while the slower 1200 and 1300 $\mathrm{K}$ data exhibited a stress exponent of about 4.6. Raj et al. concluded that this transition from high stress exponent to a lower one with decreasing temperature or increasing stress was the result of a change in deformation mechanism from dislocation-climb to viscous glide-controlled creep. Furthermore, through comparison of their $n \approx 3$ data to various models for viscous glide creep, they concluded that glide-controlled creep in $\mathrm{Ni}-30 \mathrm{Al}-20 \mathrm{Fe}-0.05 \mathrm{Zr}$ could be described by the Cottrell-Jaswon model, ${ }^{[32]}$ where the solidsolution strengthening was primarily due to $\mathrm{Fe}$ and not $\mathrm{Zr}$. 


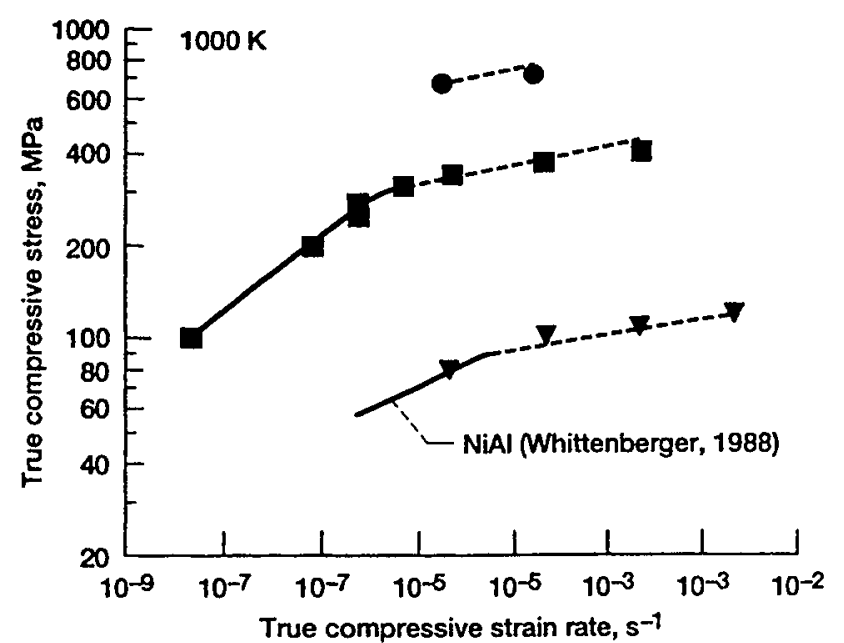

(a)

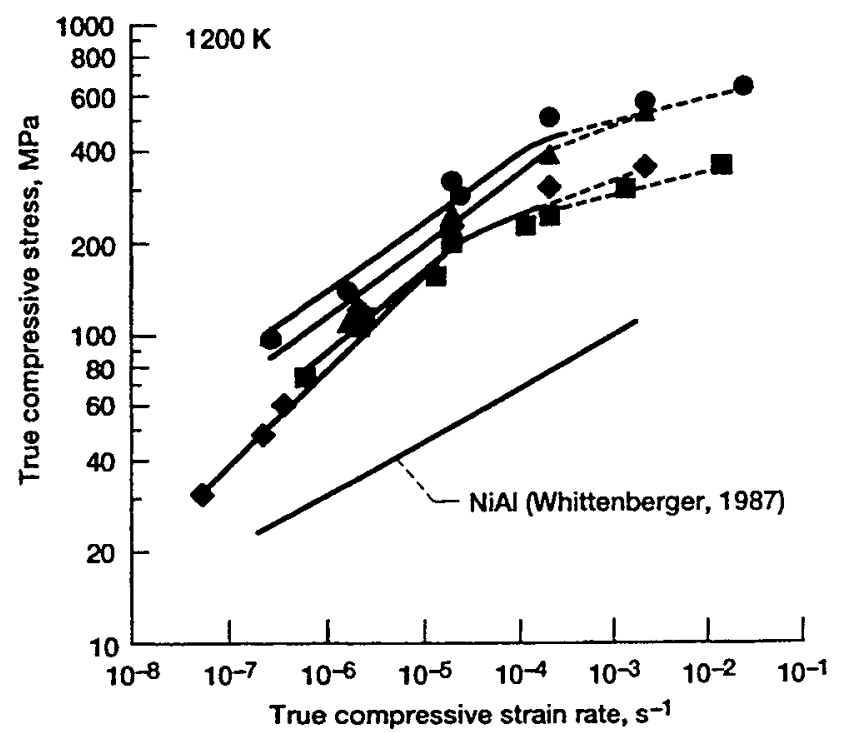

(c)

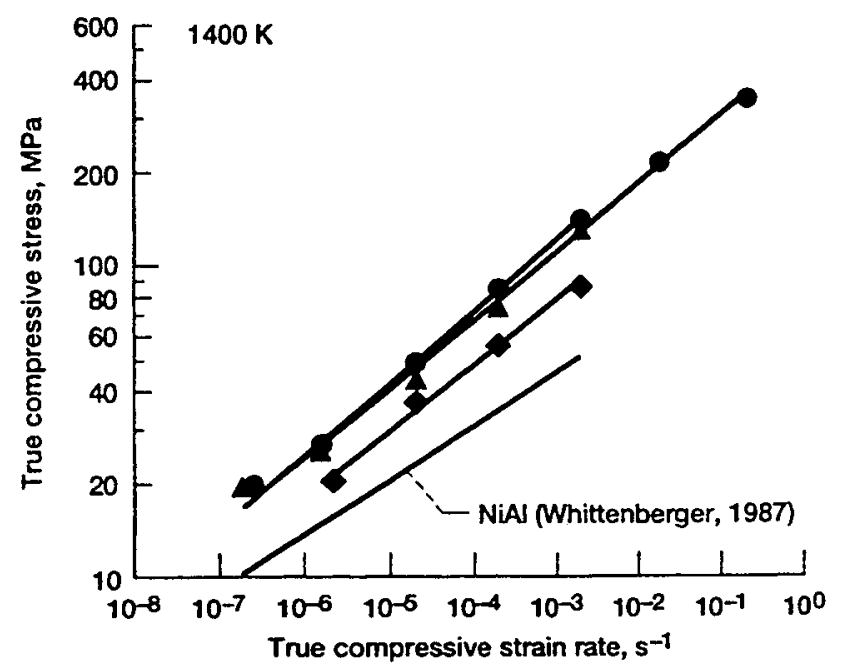

(e)

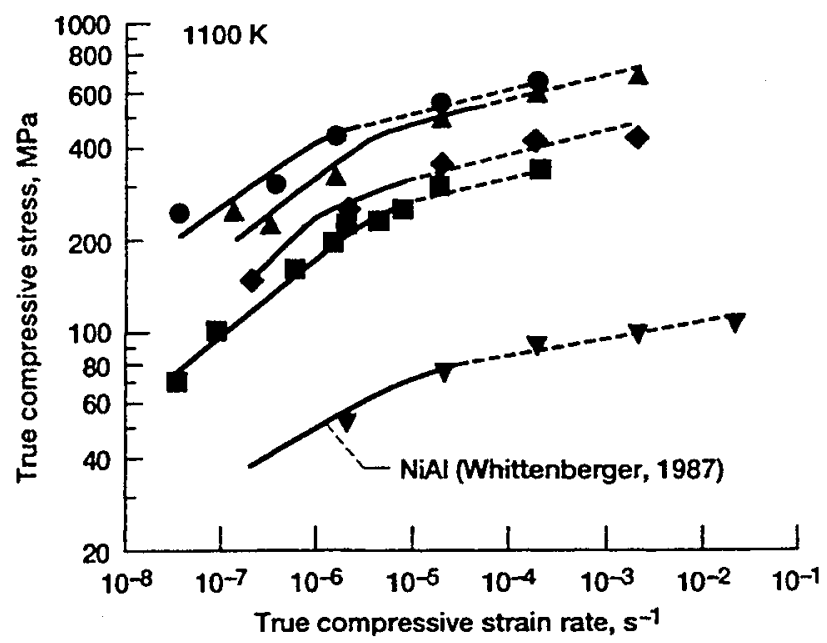

(b)

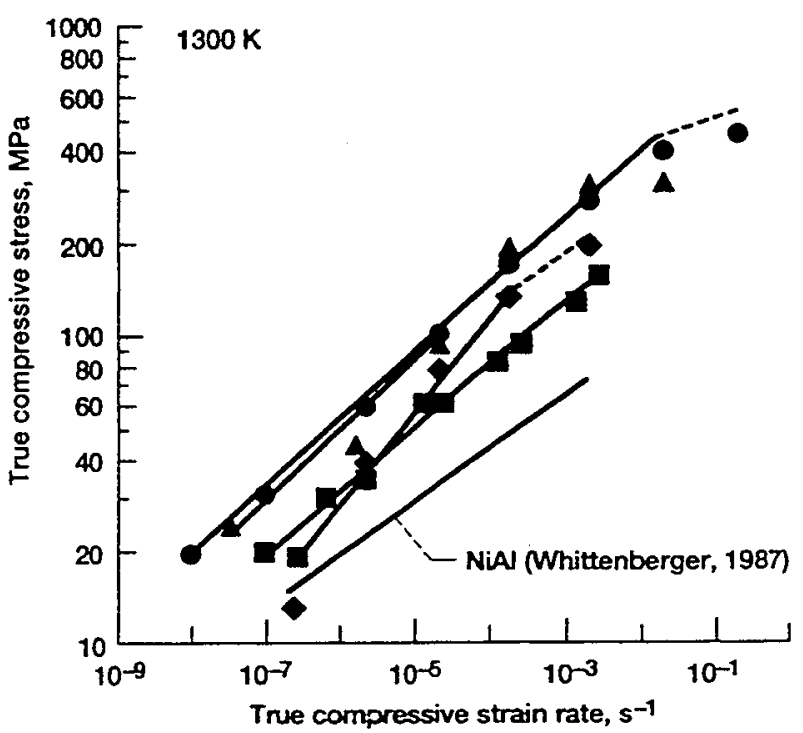

(d)

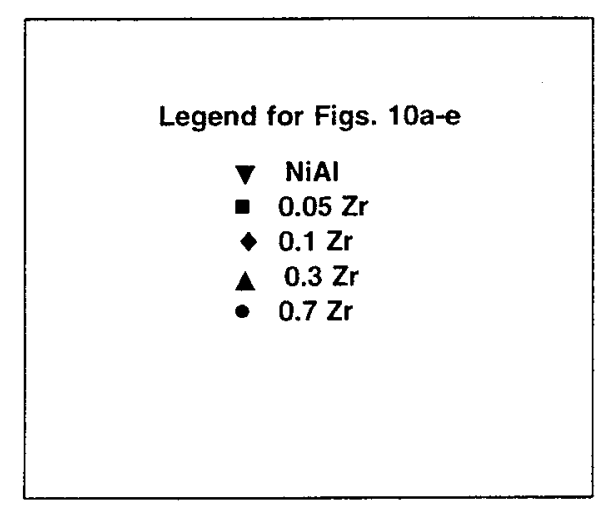

Fig. 10 -Comparison of the flow stress-strain rate properties of the $\mathrm{Zr}$-modified $\mathrm{NiAl}$ to binary $\mathrm{NiAl}$ as a function of temperature. $(a) 1000 \mathrm{~K}$, $(h)(100$ $\mathrm{K},(c) 1200 \mathrm{~K},(d) 1300 \mathrm{~K}$, and $(e) 1400 \mathrm{~K}$. Data for NiAl taken from the Appendix and Refs. 24 and 25. 
Table IV. Temperature-Compensated-Power-Law Fits of Stress-Strain Rate Data for Single-Phase and Heusler-Strengthened NiAl Alloys

\begin{tabular}{|c|c|c|c|c|c|}
\hline $\begin{array}{l}\text { Composition } \\
\text { (At. Pct) }\end{array}$ & Second Phase & $\begin{array}{c}\text { Temperature } \\
\text { Range }(\mathrm{K}) \\
\end{array}$ & Stress Exponent & $\begin{array}{c}\text { Activation } \\
\text { Energy }(\mathrm{kJ} / \mathrm{mol})\end{array}$ & Reference \\
\hline $\mathrm{Ni}-30 \mathrm{Al}-20 \mathrm{Fe}-0.05 \mathrm{Zr}$ & none & 1073 to 1300 & 2.5 to 4.6 & 310 & 29 \\
\hline $\mathrm{Ni}-45 \mathrm{Al}-5 \mathrm{Ti}$ & none & 1200 to 1300 & 3.05 & 385 & 30 \\
\hline $\mathrm{Ni}-40 \mathrm{Al}-10 \mathrm{Ti}$ & $\mathrm{Ni}_{2} \mathrm{AlTi}$ & 1200 to 1300 & 2.46 & 279 & 30 \\
\hline $\mathrm{Ni}-35 \mathrm{Al}-15 \mathrm{Ti}$ & $\mathrm{Ni}_{2} \mathrm{AlTi}$ & 1171 to 1419 & 3.53 & 275 & 12 \\
\hline $\mathrm{Ni}-47 \mathrm{Al}-0.8 \mathrm{Hf}$ & $\mathrm{Ni}_{2} \mathrm{AlHf}$ & 1200 to 1400 & 3 & 435 & 14 \\
\hline $\begin{array}{l}\text { NiAl-1 Hf } \\
\text { (single-crystal) }\end{array}$ & $\mathrm{Ni}_{2} \mathrm{AlHf}+G$ phase & 1200 to 1400 & 4.13 & 379 & 6 \\
\hline $\begin{array}{r}\mathrm{Ni}-49.5 \mathrm{Hf}-0.5 \mathrm{Hf} \\
\quad \text { (single crystal) }\end{array}$ & $\mathrm{Ni}_{2} \mathrm{AlHf}+G$ phase & 一 & 一 & 454 & 31 \\
\hline
\end{tabular}

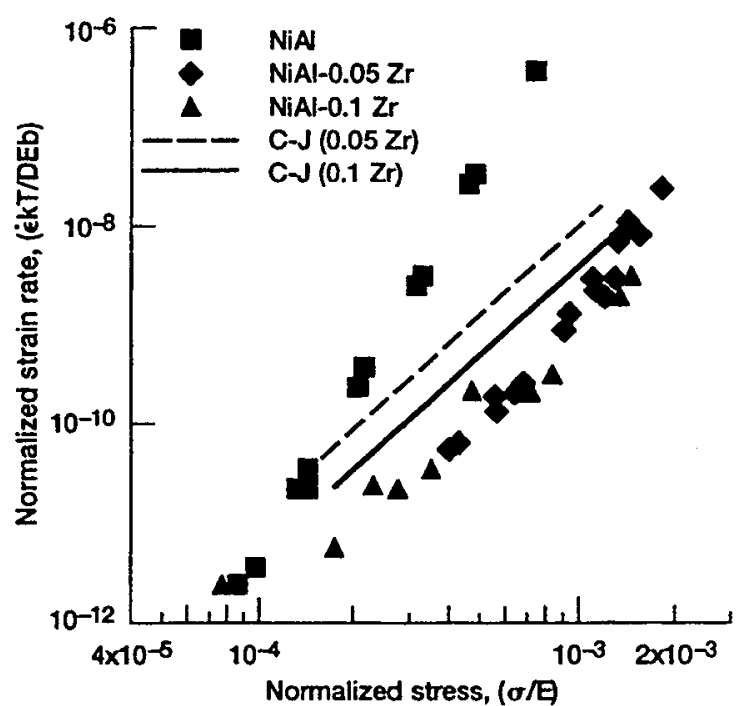

(a)

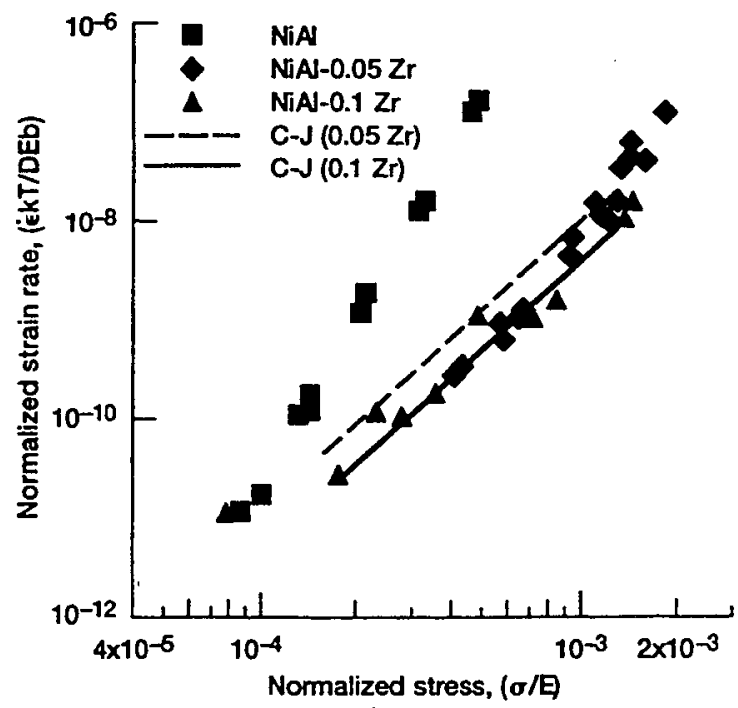

(b)

Fig. $11-(a)$ and $(h)$ Comparison of the normalized creep rate and stress for NiAl and its alloys with the predicted behavior based on the CottrellJaswon model of viscous glide controlled creep.

Following the reformulation of the Cottrell-Jaswon mechanism, as proposed by Raj et al., ${ }^{[29]}$ the normalized creep rate for viscous glide-controlled creep is given by

$$
\dot{\varepsilon} \mathrm{k} T / D E B=\left(18 / e^{2} c\right) \cdot\left(\mathrm{k} T / E \mathrm{~b}^{3}\right)^{2} \cdot(\sigma / E)^{3}
$$

where $\mathrm{k}$ is Boltzmann's constant and $c$ is the concentration of solute in mole fraction, and for $\mathrm{NiAl}$ alloys, the following apply:

$D$ is the diffusion coefficient $\approx 10^{-4} \cdot \exp$ $(-310,000 / \mathrm{R} T)$ in $\mathrm{m}^{2} / \mathrm{s}$;

$E$ is the elastic modulus $=237,000-51 T$ in $\mathrm{MPa}^{[[3.3]}$

$b$ is the magnitude of the Burgers vector $=0.2876$ $\mathrm{nm}$; and

$e$ is the solute-solvent size difference $=0.25$ for $\mathrm{Zr}$.

Normalized creep rates for $\mathrm{NiAl}$ as well as $\mathrm{NiAl}-0.05 \mathrm{Zr}$ and $\mathrm{NiAl}-0.1 \mathrm{Zr}$ are presented as a function of modulus normalized stress in Figure 11(a). For simplicity, the binary data were taken from 1100 to $1400 \mathrm{~K}$ testing of $\mathrm{Ni}$ 49.2Al, ${ }^{[25]}$ and the $\mathrm{Zr}$-modified results were restricted to those points in the $n=3$ (NiAl-0.1Zr) or 4 (NiAl-0.05Zr) regime. These data point out the large differences in strength between binary $\mathrm{NiAl}$ and its $\mathrm{Zr}$-modified alloys at high stresses and the apparent convergence of all the materials below $\sigma / E \approx 10^{-4}$. The Cottrell-Jaswon model predictions of the normalized creep rates (Eq. [3]) for $\mathrm{NiAl}-0.05 \mathrm{Zr}$ and $\mathrm{NiAl}-0.1 \mathrm{Zr}$ are represented by the dashed and solid lines, respectively, in Figure 11 . These curves were calculated for $1200 \mathrm{~K}$; estimates at higher or lower temperatures simply gave a series of very closely spaced, parallel lines bracketing the present two curves.

Although Figure 11(a) indicates that the actual strengths of $\mathrm{NiAl}-0.05 / 0.1 \mathrm{Zr}$ are greater than the predictions, these differences could simply be due to an error in the strainrate normalization procedure. If, for example, the frequency factor in the diffusion equation was $2 \times 10^{-5} \mathrm{~m}^{2} / \mathrm{s}$, instead of $10^{-4} \mathrm{~m}^{2} / \mathrm{s}$ assumed by Raj et al. ${ }^{[29]}$ normalization brings the vast majority of the data for $\mathrm{Zr}$-modified $\mathrm{NiAl}$ into coincidence (Figure 11(b)) with the Cottrell-Jaswon model.

Since a pre-exponential diffusion factor of $2 \times 10^{-5} \mathrm{~m}^{2} / \mathrm{s}$ is well within commonly accepted values for this constant, it appears that excellent agreement exists between theory and measurement. Therefore, viscous creep in $\mathrm{NiAl}-\mathrm{Zr}$ solid solutions is probably controlled by $\mathrm{Zr}$ atmospheres around gliding dislocations.

Without detailed microstructural and heat-treatment studies, little can be said about the controlling deformation 


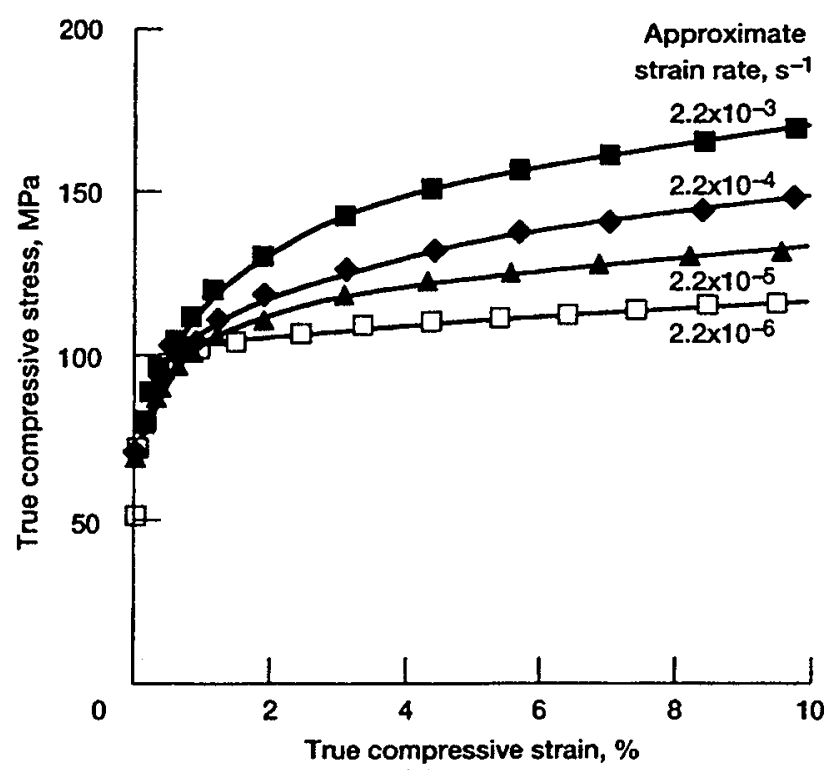

(a)

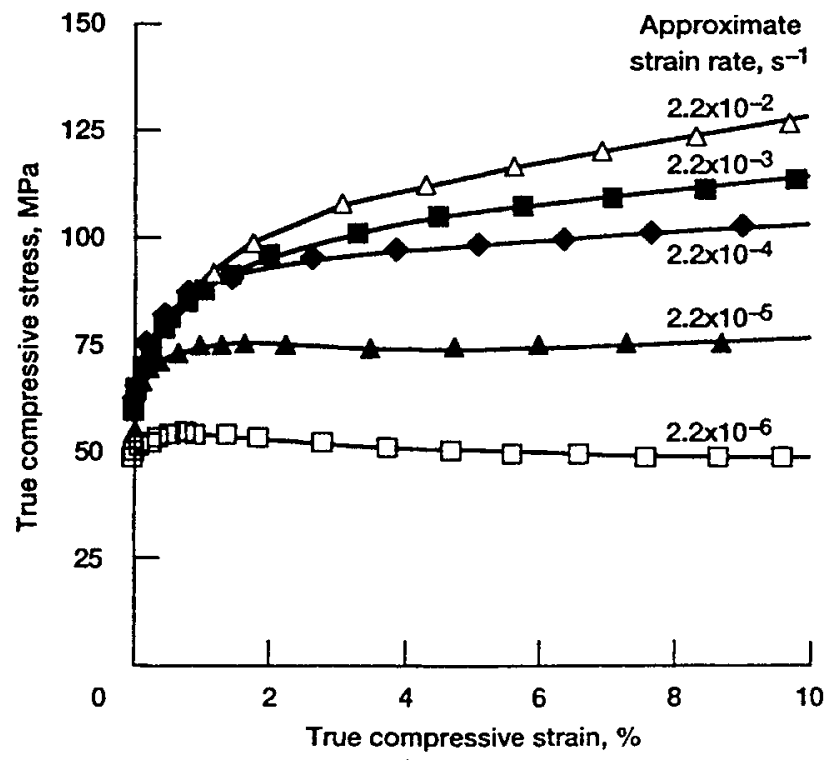

(c)

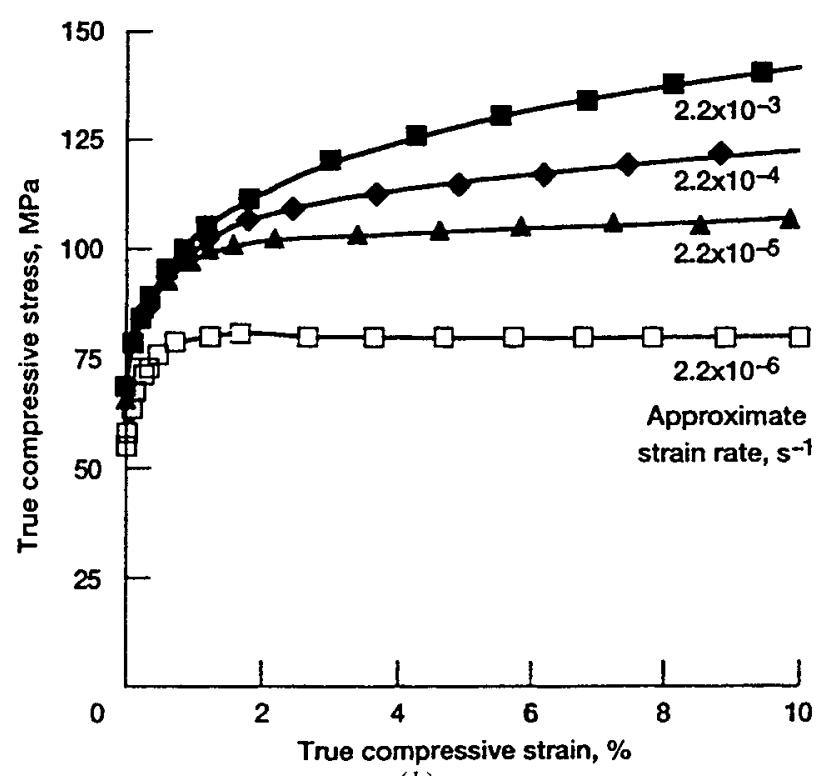

(b)

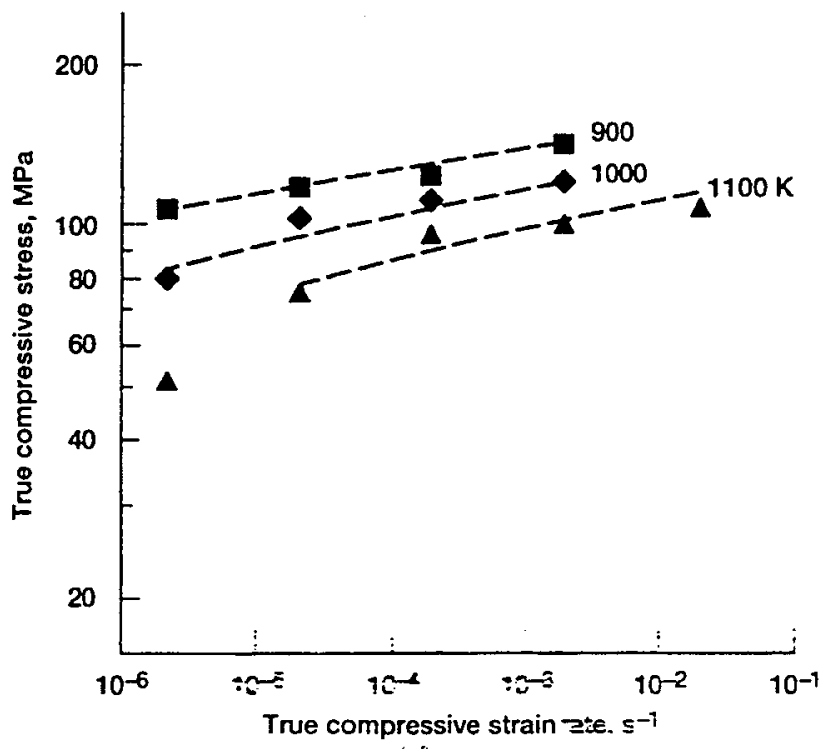

(d)

Fig. 12-True compressive stress-strain diagrams for Ni-50.6Al tested at $(a) 900 \mathrm{~K},(b) 1000 \mathrm{~K}$, and (c) $1100 \mathrm{~K}$ as a function of nominal strain rate and (d) true compressive flow stress-strain rate-temperature behavior for $\mathrm{Ni}-50.6 \mathrm{Al}$.

mechanisms in the two-phase $\mathrm{Zr}$-modified alloys (NiAl$0.3 \mathrm{Zr}$ and $\mathrm{NiAl}-0.7 \mathrm{Zr}$ ). The stress exponents and activation energies for these two materials are significantly different from those measured for other polycrystalline Heuslerstrengthened nickel aluminides. For example, $\mathrm{Ni}_{2} \mathrm{AlTi}$-containing alloys have $n \sim 3$ and $Q \sim 300 \mathrm{~kJ} / \mathrm{mol}$, while $\mathrm{NiAl}-\mathrm{Ni}_{2} \mathrm{AlHf}$ possesses a stress exponent of 3 and activation energy of $435 \mathrm{~kJ} / \mathrm{mol}$ (Table IV). The present twophase $\mathrm{Zr}$-modified materials have both higher stress exponents $(n \approx 4.5)$ and activation energies $((Q \approx 500$ $\mathrm{kJ} / \mathrm{mol}$ ) Table II(b)). In addition, both of the current $\mathrm{Ni}_{2} \mathrm{AlZr}$-strengthened alloys display similar mechanical properties, even though the volume fraction of Heusler precipitate in $\mathrm{NiAl}-0.7 \mathrm{Zr}$ is potentially three times that in $\mathrm{NiAl}-0.3 \mathrm{Zr}$. Therefore, much work remains before a reasonable understanding of $\mathrm{Zr}$-precipitation-strengthened $\mathrm{NiAl}$ can be suggested.

\section{SUMMARY OF RESULTS}

Elevated-temperature deformation has been examined between 1000 and $1400 \mathrm{~K}$ for a series of polycrystalline B2 crystal-structure nickel aluminides containing from 0.05 to 0.7 at. pct Zr. While any concentration of this third element is a potent strengthening agent under lower temperature and faster strain-rate conditions, the data for the single-phase alloys ( $\mathrm{Zr} \leq 0.1$ at. pct) do not indicate much improvement over binary NiAl for higher temperature and slower strain rate applications.

The strengthening observed in the single-phase alloys are consistent with a mechanism by which $\mathrm{Zr}$ atmospheres control creep by a viscous glide process. Two-phase NiAl$\mathrm{Ni}_{2} \mathrm{AlZr}$ alloys, however, do display strength advantages over single-phase materials under all test conditions. Surprisingly, resistance to deformation was not significantly 
affected by the amount of the second phase, with both $\mathrm{NiAl}-0.3 \mathrm{Zr}$ and $\mathrm{NiAl}-0.7 \mathrm{Zr}$ displaying similar mechanical properties. Oxidation resistance, on the other hand, was affected by $\mathrm{Zr}$ content, where the degree of microstructural damage was worst in the highest $\mathrm{Zr}$-level alloy.

\section{CONCLUSIONS}

Based on the strength properties and microstructural damage from oxidation of polycrystalline $\mathrm{Zr}$-modified $\mathrm{NiAl}$, it is concluded that optimum elevated-temperature behavior (high strength and adequate oxidation resistance) could be obtained in two-phase, Heusler-strengthened NiAl containing between 0.1 and 0.3 at. pet $\mathrm{Zr}$.

\section{APPENDIX \\ 900 to $1100 \mathrm{~K}$ stress-strain-strain rate behavior of Ni-50.6Al}

To extend the range of flow stress-strain rate-temperature data for binary $\mathrm{NiAl}$, compression samples were cut from a bar of hot extruded Ni-50.6Al powder and tested under constant-velocity conditions between 900 and 1100 $\mathrm{K}$ in the same manner as described in Section II. The alloy composition, consolidation procedures, and grain size are noted in Table I. The same heat of material was also tested in References 16, 17, and 20.

True compressive stress-strain curves from the constant-velocity testing are presented as a function of temperature and nominal strain rate in Figures 12(a) through (c). These curves possess similar characteristics under all test conditions, where rapid work hardening occurs over the first $\sim 2$ pct strain and is followed by much slower strain hardening for the faster deformation/lower temperature conditions or by continued flow under an approximately constant stress. The flow stress-strain rate data, taken at 3 pct strain from Figures 12(a) through (c), are shown in Figure 12(d). With the exception of the slowest strain-rate result for $1100 \mathrm{~K}$, the data could be adequately described by a temperature-compensated exponential law (Eq. [1]), and the appropriate parameters for this description are reported in Table II. The activation energy of 317 $\mathrm{kJ} / \mathrm{mol}$ from this analysis is identical to the $314.2 \mathrm{~kJ} / \mathrm{mol}$ activation energy reported for a temperature-compensated power law fit of 1100 to $1400 \mathrm{~K}$ data from $\mathrm{NiAl}$ containing from 44 to $50.6 \mathrm{Al}^{[24]}$

\section{REFERENCES}

1. R. Darolia: JOM, 1991, vol. 43 (3), pp. 44-49.

2. C.T. Liu and K.S. Kumar: JOM, 1993, vol. 45 (5), pp. 38-44.

3. D.B. Miracle: Acta Metall. Mater., 1993, vol. 41, pp. 649-84.

4. R.D. Noebe, R.R. Bowman, and N.V. Nathal: Int. Mater. Rev., 1993, vol. 38 , pp. 193-232.
5. R. Darolia: in Structural Intermetallics, R. Darolia, J.J. Lewandowski, C.T. Liu, P.L. Martin, D.B. Miracle, and M.V. Nathal, eds., TMS, Warrendale, PA, 1993, pp. 495-504.

6. 1.E. Locci, R. Dickerson, R.R. Bowman, J.D. Whittenberger, M.V Nathal, and R. Darolia: in High-Temperature Ordered Intermetallic Allovs V, I. Baker, R. Darolia, J.D. Whittenberger, and M.H. Yoo, eds., Materials Research Society, Pittsburgh, PA, 1993, vol. 288, pp 685-90.

7. W.S. Walston. R.D. Field, J.R. Dobbs, D.F. Lahrman, and R. Darolia: in Structural Intermetallics, R. Darolia, J.J. Lewandowski, C.T. Liu, P.L. Martin, D.B. Miracle, and M.V. Nathal, eds., TMS, Warrendale, PA, 1993, pp. 523-32.

8. R.D. Noebe, R.R. Bowman, and M.V. Nathal: NASA TP-3398, 1994

9. D.P. Mason, D.C. Van Aken, R.D. Noebe, I.E. Locci, and K.L. King: in High Temperature Ordered Intermetallic Allovs IV, L.A. Johnson, D.P. Pope, and J.O. Stiegler, eds., Materials Research Society, Pittsburgh, PA, 1991, vol. 213, pp. 1033-38.

10. E.P. George and C.T. Liu: J. Mater. Res., 1990, vol. 5, pp. 754-62.

11. R.D. Noebe and A. Garg: Scripta Metall. Mater., 1994, vol. 30, pp. 815-20.

12. R.S. Polvani, Wen-Shian Tzeng, and P.R. Strutt: Metall. Trans. A, 1976, vol. 7A, pp. 33-40.

13. K. Vedula, V. Pathare, I. Aslandis, and R.H. Titran: in HighTemperature Ordered Intermetallic Alloys, C.C. Koch, C.T. Liu, and N.S. Stoloff, eds., Materials Research Society, Pittsburgh, PA, 1985, vol. 39, pp. $411-21$.

14. J.D. Whittenberger, M.V. Nathal, S.V. Raj, and V.M. Pathare: Mater. Lett., 1991, vol. 11, pp. 267-73.

15. J.D. Whittenberger, L.J. Westfall, and M.V. Nathal: Scripta Metall, 1989, vol. 23, pp. 2127-30.

16. S.V. Raj, R.D. Noebe, and R. Bowman: Scripta Metall., 1989, vol. 23, pp. 2049-54.

17. R.R. Bowman, R.D. Noebe, S.V. Raj, and I.E. Locci: Metall. Trans $A, 1992$, vol. 23A, pp. 1493-1508.

18. R.D. Noebe and M.K. Behbehani: Scripta Metall. Mater., 1992, vol. 27, pp. 1795-1800.

19. M.V. Zeller, R.D. Nocbe, and I.E. Locci: NASA CP-10051, 1990, pp 21-1-21-17.

20. R.D. Noebe: NASA TM 106534, 1994

21. R.D. Noebe, B.A. Lerch, and K.B.S. Rao: in High Temperature Ordered Intermetallic Alloys VI. Part I, J.A. Horton, I. Baker, S. Hanada, R.D. Noebe, and D.S. Schwartz, eds., Materials Research Society, Pittsburgh, PA, 1995, vol. 364, pp. 291-296.

22. C.A. Bartett: Oxid. Met., 1988, vol. 30, pp. 361-90.

23. R.R. Bowman and R.D. Noebe: NASA-Lewis Research Center, Cleveland, $\mathrm{OH}$, unpublished research, 1992.

24. J.D. Whittenberger: J. Mater. Sci., 1987, vol. 22, pp. $394-402$

25. J.D. Whittenberger: J. Mater. Sci., 1988, vol. 23, pp. 235-40.

26. S.V. Raj and S.F. Farmer: in High-Temperature Ordered Intermetallic Allovs V, I. Baker, R. Darolia, J. Daniel Whittenberger, and M.H Yoo, eds., Materials Research Society, Pittsburgh, PA, 1993, vol. 288, pp. 647-52.

27. S.V. Raj and S.F. Farmer: Metall. Mater. Trans. A, 1995, vol. 26A, pp. $343-56$.

28. T.G. Langdon: in Strength of Metals and Allovs (ICSMA 6), R.C Gifkins, ed., Pergamon Press, New York, NY, 1983, pp. 1105-20.

29. S.V. Raj, I.E. Locci, and R.D. Noebe: Metall. Trans. A, 1992, vol. 23A, pp. 1705-18.

30. J.D. Whittenberger, R.W. Viswanadham, S.K. Mannan, and K.S. Kumar: J. Mater. Res., 1989, vol. 4, pp. 1164-71.

31. R.D. Field: General Electric Aircraft Engines, Cincinnati, OH, unpublished research, 1993.

32. A.H. Cottrell and M.A. Jaswon: Proc. R. Soc., 1949, vol. A199. pp. 104-14.

33. M.R. Harmouche and A. Wolfenden: J. Test. Elal., 1987, vol. 15, pp. 101-04. 